\title{
The Triassic/Jurassic boundary and the Jurassic stratigraphy and biostratigraphy of northern Sonora, northwest Mexico
}

\author{
Carlos M. González-León, George D. Stanley, Jr., Timothy F. Lawton, József Pálfy, Montana S. Hodges
}

Carlos M. González-León

cmgleon@unam.mx

Universidad Nacional Autónoma de México, Instituto de Geología, Estación Regional del Noroeste, Apartado Postal 1039, Hermosillo, Sonora, México, 83000

\section{George D. Stanley, Jr.}

Montana S. Hodges

University of Montana Paleontology Center, 32 Campus Drive, Missoula, Montana, 59812, USA.

\section{Timothy F. Lawton}

Universidad Nacional Autónoma de México, Centro de Geociencias, Blvd. Juriquilla 3001, Juriquilla, Querétaro, Qro., México, 76230.

\section{József Pálfy}

Department of Physical and Applied Geology, Eötvös Loránd University, Pázmány Péter sétány 1/C, Budapest, H-1117 Hungary.

MTA-MTM-ELTE Research Group for Paleontology, POB 137, Budapest, H-1431 Hungary.

BOL. SOC. GEOL. MEX. 2017

VOL. 69 NO. 3

P. $711-738$

\begin{abstract}
The Triassic and Jurassic geology of northern Sonora encompasses important events that are linked to the late Paleozoic history of the region. The fossiliferous $\mathrm{El}$ Antimonio Group in the Sierra del Álamo includes the upper Permian-Triassic Antimonio, and Río Asunción formations and the Hettangian-Sinemurian Sierra de Santa Rosa Formation. These formations consist of upward-fining sequences from I to XIV that represent fluvial to shallow and deep marine environments of deposition. The Triassic/Jurassic boundary in this region is a hiatus represented by a disconformity between sequence IX of the Río Asunción formations and sequence $\mathrm{X}$ of the Sierra de Santa Rosa Formation. The shallow to deep marine succession of the Sierra de Santa Rosa composes the upper part of the Sierra de Santa Rosa Formation that ranges in age from late Sinemurian to early Pliensbachian. Ages of the Permian to Triassic plutonic rocks of northwesternmost Sonora, the Mojave Desert and the Jurassic continental margin Nazas arc that crossed through northern Sonora, are also well recorded by igneous clasts and detrital zircon grains that have been dated from the El Antimonio Group and other Jurassic formations of this region. The upper Oxfordian-lower Tithonian Cucurpe Formation in north-central Sonora recorded the onset of continental extension and incursion of marine waters from the Gulf of Mexico into northwestern Mexico, once activity of the Jurassic magmatic arc ended.
\end{abstract}

Keywords: Triassic-Jurassic, El Antimonio Group, Sierra de Santa Rosa Formation, Cucurpe Formation, biostratigraphy.

\section{RESUMEN}

La historia triásica y jurásica del norte de Sonora abarca importantes eventos que están vinculados a la historia del Paleozoico tardío de la región. El Grupo El Antimonio que aflora en la Sierra del Álamo incluye las formaciones Antimonio y Rio Asunción del Pérmico tardio - Triásico Tardío y a la Formación Sierra de Santa Rosa que tiene edad Hettangiana-Sinemuriana. Estas formaciones están compuestas por secuencias grano-decrecientes que se han numerado de la I a la XIV y representan ambientes de depósito que van de fluviales a marinos profundos. El límite Triásico/ furásico en esta región es un hiato representado por una disconformidad entre la secuencia $I X d e$ la Formación Río Asunción y la secuencia $X$ de la Formación Sierra de Santa Rosa. La sucesión marina somera a marina profunda de la Formación Sierra de Santa Rosa que aflora en la sierra del mismo nombre constituye la parte superior de dicha formación cuya edad se extiende del Sinemuriano tardío al Pliensbachiano temprano. Las edades del magmatismo Pérmico y Triásico que ocurrió en el noroeste de Sonora y en el desierto Mojave del suroeste de Estados Unidos, así como las del magmatismo del arco continental Nazas que atravesó el norte de Sonora durante el Furásico, están bien registradas en edades obtenidas en clastos ígneos y en circones detríticos que se han fechado del Grupo El Antimonio y otras formaciones furásicas de la región. La Formación Cucurpe del Jurásico Tardío (Oxfordiano tardío

- Titoniano temprano) registra, en el centro-norte de Sonora, el inicio de una extensión continentaly la incursión de aguas marinas del Golfo de México una vez que concluyó la actividad del arco magmático jurásico.

Palabras clave: Triásico-Jurásico, Grupo El Antimonio, Formación Sierra de Santa Rosa, Formación Cucurpe, Bioestratigrafía. 


\section{Introduction}

The region of the North American Cordillera that includes northern Sonora, southern Arizona and southeastern California is a geologically complex area that was built upon the southern termination of the Proterozoic basement rocks of the Mojave, Yavapai and Mazatzal provinces of the United States. In most of this region, these basement rocks are overlain by miogeoclinal carbonate and siliciclastic strata from Neoproterozoic to Paleozoic ages (Stewart, 2005).

Some of the main events that affected this region and shaped the Mesozoic history include truncation of the Proterozoic and Paleozoic rocks in a northwest-southeast direction during the late Paleozoic (Stevens et al., 2005 and references therein). Following truncation of this margin, an eastward-dipping subduction zone that initiated in early Permian time led the construction of a magmatic arc along the continental margin. The arc magmatic activity ended by Middle-Late Triassic time and resumed again in Early Jurassic. Although southeast-directed tectonic transportation of the Caborca block, from its original position in southern California to its present position in Sonora, is a widely accepted idea, debate remains whether it was transported by sinistral strike-slip faults during the late Paleozoic (Stone and Stevens, 1988; Dickinson, 2000; Lawton et al., 2017) or by the Mojave-Sonora megashear (Anderson and Silver, 2005) in Late Jurassic time. However, an alternative hypothesis considers the Caborca block as autochthonous (Poole et al., 2005).

Contemporaneous with the Permo-Triassic and Early Jurassic arcs there was a marine to marginal marine fore-arc basin, situated at the south of the arc, where sedimentation of the El Antimonio Group occurred. The El Antimonio basin was connected to the east with a continental and marginal marine basin in central Sonora where the coeval Barranca Group strata accumulated (Alencáster de Ciserna, 1961).

The extensional Jurassic magmatic arc developed in northern Sonora ended when the rift-related extension that connected to the Gulf of Mexico allowed marine waters to invade the region of central Sonora during Late Jurassic time (Mauel et al., 2011 and references therein). A contemporaneous and parallel rift reached northeastern Sonora, southeastern Arizona and southwestern New Mexico to form the early Bisbee basin.

In northern Sonora, a west-to-east transect through scattered outcrops of Triassic and Jurassic strata provides an almost complete record of the stratigraphic, paleontological and tectonic history of the early Mesozoic. The most complete sections of the Permo-Triassic Antimonio and Río Asunción Formations as well as the Early Jurassic Sierra de Santa Rosa Formation of the El Antimonio Group crop out in the Sierra del Álamo in the western part of the transect, whereas the youngest part of the Sierra de Santa Rosa Formation crops out in the Sierra de Santa Rosa. The most complete sections of the Jurassic magmatic arc rocks have been studied in the Cucurpe region of north-central Sonora. Moreover, the best outcrops that record the inland incursion of the Gulf of Mexico waters are shown in the Upper Jurassic Cucurpe Formation

During this field-trip we will visit exclusively parts of the El Antimonio Group and the Cucurpe Formation due to they are geographically separated outcrops and not easy to access. In the Sierra del Álamo we will visit the higher part of the Upper Triassic Río Asunción Formation and its transition to the Lower Jurassic Sierra de Santa Rosa Formation. In the Sierra de Santa Rosa we will visit the lower and middle members of the Sierra de Santa Rosa Formation, and, on the third day, we will go to the Cucurpe region to visit the Cucurpe Formation in its incomplete outcrop at Rancho La Colgada. What follows is an extended and updated summary for the purpose of documenting the Mesozoic geology of this region.

\subsection{EL ANTIMONIO GROUP}

The most complete stratigraphic succession of the mostly marine, Permian-Triassic and Lower Jurassic strata of Sonora is exposed in the Sier- 
ra del Álamo and Sierra de Santa Rosa localities in northwestern Sonora (Figure 1). An early description of these rocks was made on the Triassic and Jurassic paleontology of both localities (Keller, 1928). Early stratigraphic work on the Permian rocks of Cerro Monos, in the northern part of the Sierra del Álamo was conducted by Cooper and Arellano (1946), who named this $c a .500 \mathrm{~m}$ thick siliciclastic and carbonate succession the Monos Formation. White and Guiza (1949) reported the stratigraphy for these Triassic rocks and noted their unconformity with the Monos Formation. A complete report on the paleontology of the Monos Formation was presented in Cooper et al. (1953). González-León (1980) mapped the $3.4 \mathrm{~km}$ thick stratigraphic succession of the Sierra del Álamo and divided it into a lower member and an upper member as belonging to Late Triassic and Early Jurassic age, respectively; both members were assigned to the Antimonio Formation. A partly cor- relative Lower Jurassic section that was studied in detail in the Sierra de Santa Rosa was assigned to the Sierra de Santa Rosa Formation (Hardy, 1981). Other incomplete sections of these strata are scattered at several localities from central to northwestern Sonora (see González-León et al., 2011).

Subsequent lithostratigraphic and paleontological studies established that the Antimonio Formation consists of 14 upward-shallowing, unconformity bounded sequences (sequences I through XIV), each grading from fluvial to shallow and deep marine environments upwards (González-León, 1997a) (Figure 2), these studies also concluded that the lower part of the Antimonio Formation ranges from the upper Permian to the Upper Triassic (Stanley et al., 1994; Damborenea and GonzálezLeón, 1997; Estep et al., 1997a, 1997b; Lucas et al., 1997a, 1997b). González-León et al. (1996) recognized the Triassic-Jurassic boundary in this

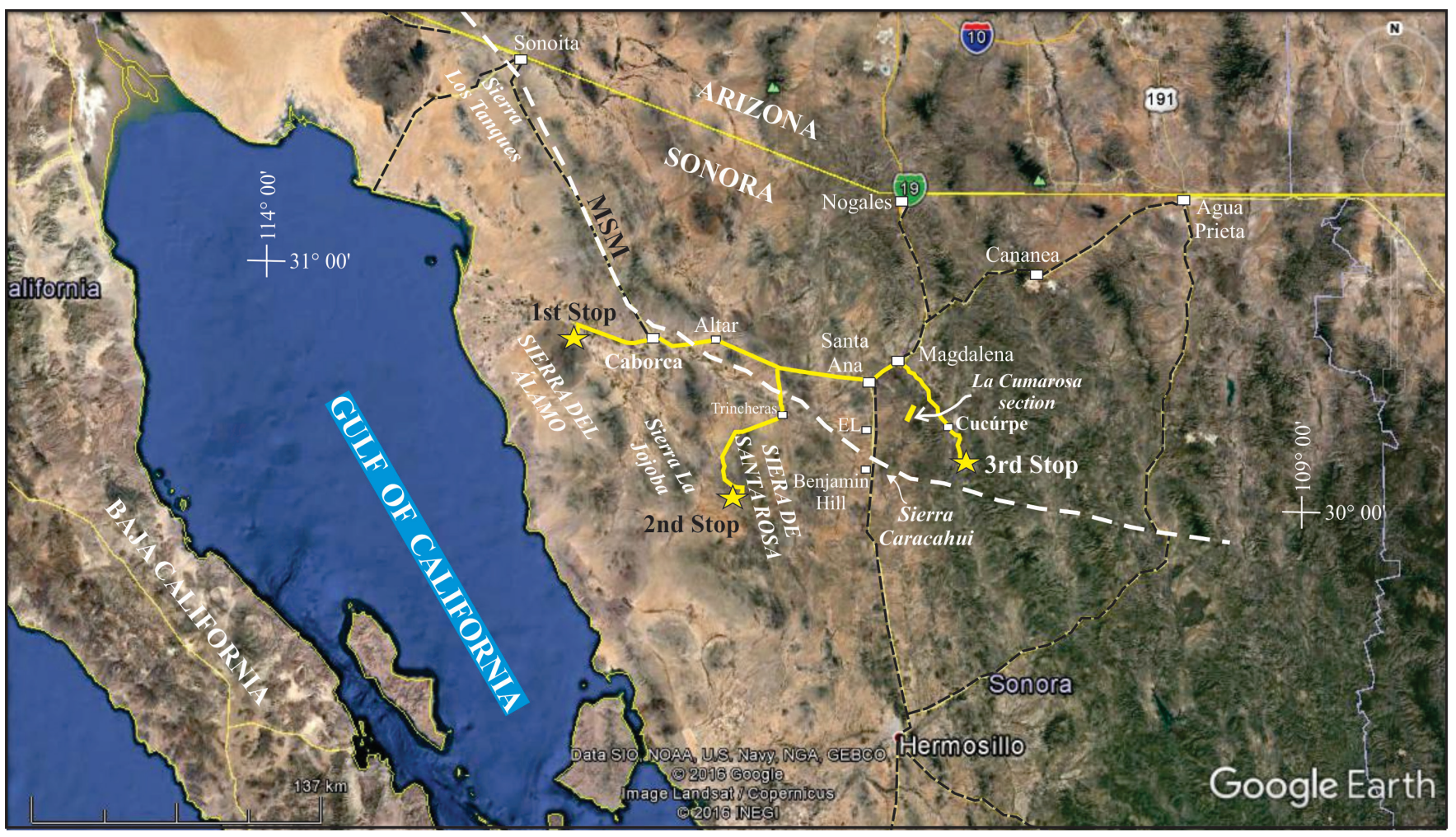

Figure 1 Base map of northern Sonora and adjacent areas taken from Google Earth (December, 2016). It shows main roads (black dashed lines), towns (white squares) and location of outcrops (yellow stars) to visit in stops 1 to 3 during this field-trip. Other localities mentioned in the manuscript are indicated. Dashed line labeled as MSM indicate approximate trace of the Mojave-Sonora megashear after Anderson and Silver (2005). 
formation and Lucas et al. (1997a) recognized the Permian-Triassic boundary. Further details on the Triassic-Jurassic contact were published by González-León (1997b), Lucas and Estep (1999a) and González-León et al. (2000).

Lucas and Estep (1999b) revised the use of the Antimonio Formation of the Sierra del Álamo and subdivided the succession into the Antimonio, Río Asunción and Sierra de Santa Rosa formations that were later grouped into El Antimonio Group (González-León et al., 2005). The Antimonio Formation of Lucas and Estep (1999b) comprises sequence I through sequence VI encompassing upper Permian to Upper Triassic (Carnian) strata. González-León et al. (2005), based on updated fossil identifications, reassigned sequences VII to IX to the Río Asunción Formation and sequences X to XIV to the Sierra de Santa Rosa Formation,. The following summarized description of these formations is taken from González-León et al. (2005).

\subsubsection{ANTIMONIO FORMATION}

Sequences I to VI, which compose the Antimonio Formation, range from 100 to $500 \mathrm{~m}$ in thickness and are subdivided into seven units (Figure 2). Sequence I disconformably overlies the Permian Monos Formation and consists of calcareous red siltstone, subordinate limestone, fine-grained sandstone and uncommon thin pebble conglomerate. Brachiopods in this sequence that are also common in the Monos Formation suggest a Guadalupian age (Lucas et al., 1997a). Nevertheless, the Monos Formation might be reassigned to the uppermost Permian according to preliminary results reported by Dobbs et al. (2016), who dated detrital zircons as young as $258 \mathrm{Ma}$.

Sequence II consists of a basal fluvial conglomerate that is overlain by shallow-marine calcareous red siltstone and sandstone that grades upward into limestone beds with shell remains. The Permian-Triassic boundary was placed tentatively at the base of this sequence (Lucas et al., 1997a), and Steiner et al. (2005) suggested an Early Triassic (Dienerian) age based on magnetostratigraphy. Sequence III consists of a fluvial conglomerate that has reworked clasts from the Monos Formation that bear the foraminifera Parafusulina antimoniensis that was reported in that formation by Dunbar (1953) (González-León, 1997a). It grades upwards into sandstone, siltstone and sandy to muddy limestone with ammonoids and conodonts that indicate an Early Triassic (Spathian) age (Lucas et al., 1997b). Sequence IV, although poorly exposed, grades upwards from a clast-supported fluvial conglomerate into marine red sandstone, siltstone, and limestone with ammonoids of Anisian age (Estep et al., 1997a). Similarly, sequence $\mathrm{V}$ grades from clast-supported conglomerate into red sandstone, siltstone and limestone with aulacoceratid cephalopods, ammonoids and ichthyosaur bones, probably of the Ladinian or Carnian stage (González-León, 1997a).

The uppermost sequence VI of the Antimonio Formation consists of shallow marine pebbly sandstone that grades upward into sandstone, siltstone and an upper package of massive to finely laminated red mudstone, bioclastic limestone, and fine-grained sandstone with abundant fossils of Carnian age (Keller, 1928; Burckhardt, 1930; Callaway and Massare, 1989; Lucas and GonzálezLeón, 1995; Estep et al., 1997b, Lucas et al., 2015). Lucas et al. (2015) documented the ammonoid assemblage in this package, recognizing the Carnian Sirenites nanseni, Tropites dilleri and Tropites welleri zones.

\subsubsection{RÍO ASUNCIÓN FORMATION}

Sequence VII, in the lower part of the Río Asunción Formation, has a basal unit (unit 12, Figure 2) of fluvial pebble conglomerate and sandstone that grades upward to calcareous sandstone and coquinoid limestone with bivalves in the middle part of this sequence. The upper part (unit 13) consists of medium to thick-bedded, fossiliferous biostromal limestone with interbedded mudstone and fine-grained sandstone. The biostromes are constructed by abundant scleractinian corals and chambered sponges disjectoporoids and the hydrozoan Heterastridium together with mollusks (ammonoids, gastropods and bivalves), brachiopods and other invertebrate fossils (Stanley et al., 1994; 

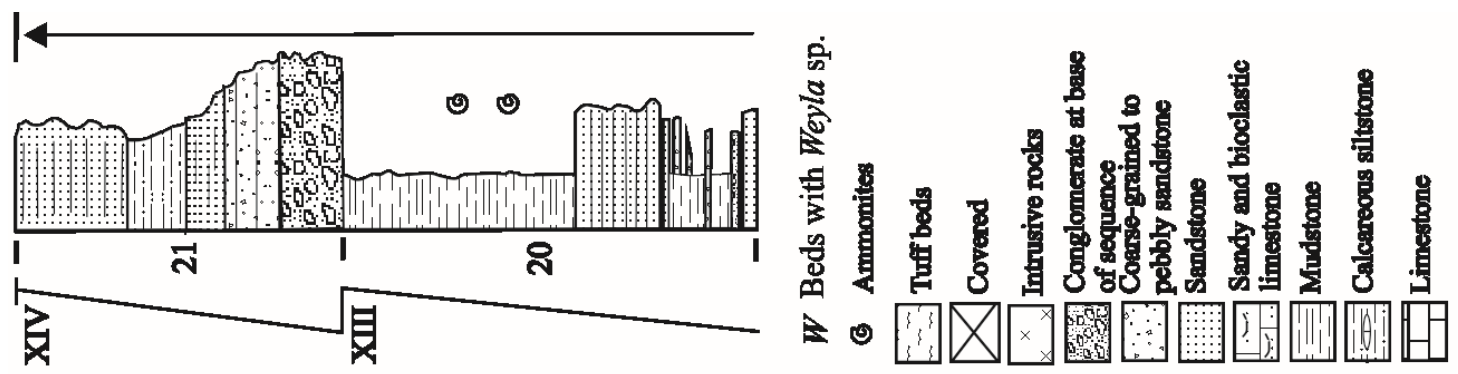

(7IBd IOMOT)

NOILVTYOA VSOY VINVS GC VYYGIS

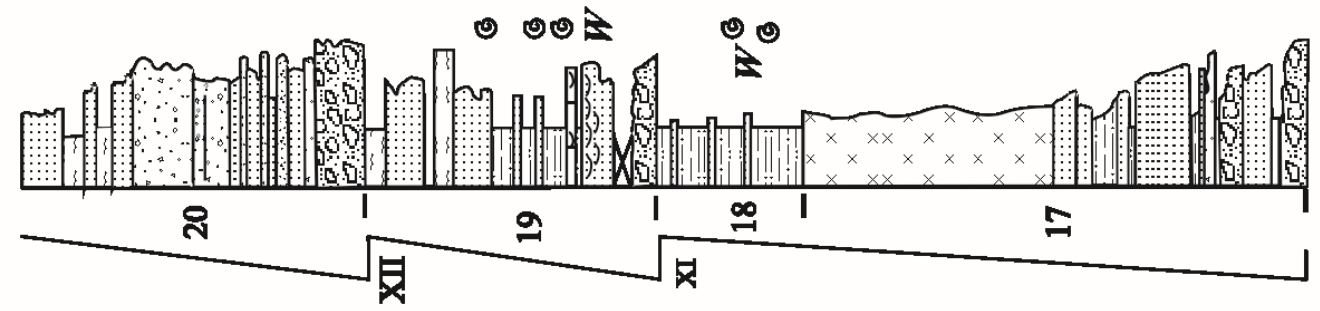

\section{$\left.\longrightarrow\right|_{00}{ }_{0}$ NOILYNYOA NOIONASV OIY $\longrightarrow$}
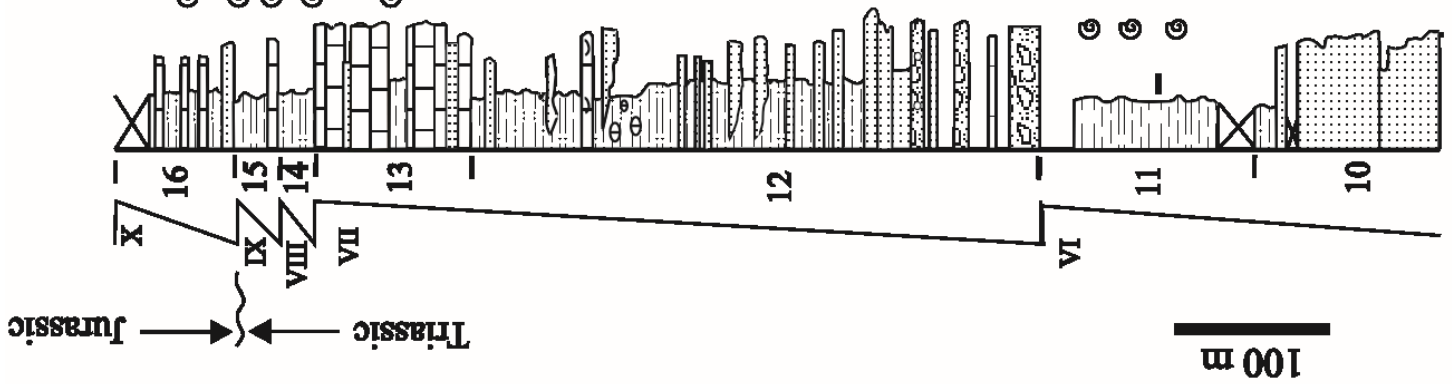

NOILYWYOA OINOWILNY
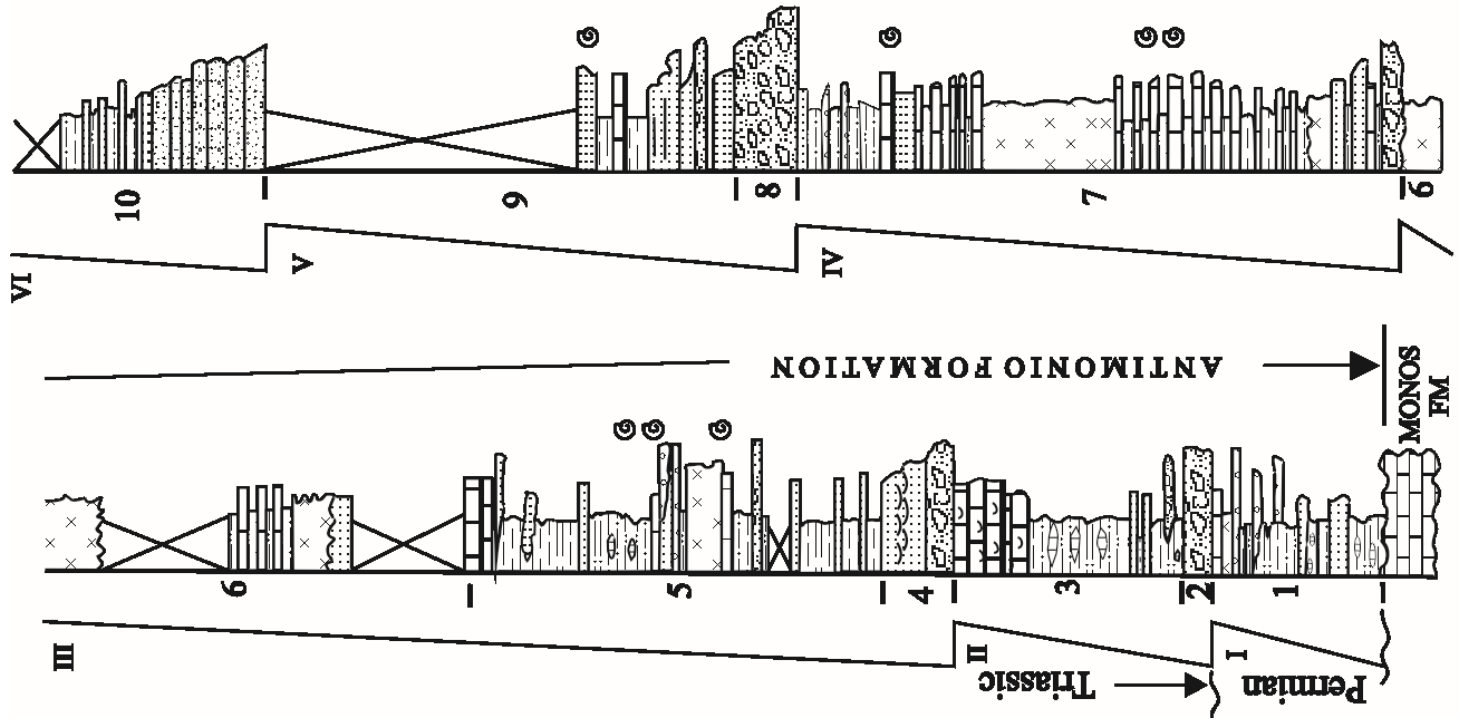
González-León et al., 1996; McRoberts, 1997; Damborenea and González-León, 1997; Goodwin and Stanley, 1997; Stanley and GonzálezLeón, 1997; Goodwin, 1999). Ammonoids and the spherical Heterastridium conglobatum (Stanley et al., 1994) allow assignment of the sequence to the late Norian.

Sequence VIII is a $17 \mathrm{~m}$ thick unit consisting of massive calcareous siltstone with bivalves, crinoids and ammonoids from the Rhaetian Amoenum Zone. The lower limestone beds of the overlying sequence IX consist of bioclastic and sandy limestone beds, 2 to $8 \mathrm{~m}$ thick with abundant, diverse and reworked ammonoids, bivalves, colonial corals, nautiloids, crinoids, bones and teeth that probably belong to ichthyosaurs and fishes. The ammonoids Rhacophyllites, Sagenites and the Rhaetian index genus Choristoceras were identified from these beds (González-León et al., 2000). Sequence IX varies in thickness from 27 to $43 \mathrm{~m}$ and consists of calcareous siltstone, fine-grained sandstone and dark gray laminated to massive mudstone. The mudstone in the uppermost meters of the sequence contains specimens of Rhabdoceras cf. R. suessi Hauer and Choristoceras cf. C. nobile Mojsisovics that characterize the Rhaetian Crickmayi Zone (González-León et al., 2000).

The stratigraphic contact between sequences IX and X represents the Triassic/Jurassic boundary in the El Antimonio Group (González-León, 1997b; Lucas and Estep, 1999a; González-León et al., 2000) but the contact is a disconformity making a hiatus. It also represents the contact between the Norian to Rhaetian Río Asunción Formation and the Lower Jurassic Sierra de Santa Rosa Formation (González-León et al., 2000). The boundary is regarded as a disconformity surface, and the lower Hettangian strata are missing. So, the Triassic-Jurassic boundary section, once thought continuous, is incomplete.

\subsubsection{SIERRA DE SANTA ROSA FORMATION IN THE SIERRA DEL ÁLAMO}

The Sierra de Santa Rosa Formation consists of sequences X to XIV in the Sierra del Álamo but its upper part is missing because of faulting. The missing upper part crops out in the Sierra de Santa Rosa locality, where sequences were not defined. The lower part of the $60 \mathrm{~m}$ thick sequence $\mathrm{X}$ is composed of a base-erosive, laterally continuous, coarse-grained to pebbly sandstone that fines upwards into calcareous siltstone, containing the ammonoid Sunrisites sunrisensis Guex (GonzálezLeón et al., 1996). This ammonoid characterizes the uppermost Hettangian Sunrisense Zone (Taylor et al., 2001). The upper part of this sequence is composed of interbedded siltstone, dark gray calcareous mudstone and up to $1 \mathrm{~m}$ thick bioclastic limestone beds with ammonoids and bivalves. Coroniceras $\mathrm{n}$. sp. of the middle part of this sequence was assigned by Taylor et al. (2001) to the lower Sinemurian Trigonatum Zone, while Badouxia mexicana and $B$. canadensis in these beds have a range that straddles the uppermost Hettangian and lowermost Sinemurian stages (see fig. 3 in Taylor et al., 2001). Bivalves of this sequence, including Weyla (Lywea) unca, were described by Scholz et al. (2008). The lower part of sequence XI is marked by a 20 $\mathrm{m}$ thick, upward-fining, clast-supported pebble conglomerate that grades upward into sandstone and siltstone of fluvial origin. Most of the middle part of the sequence is cut out by a dioritic intrusion, and its upper part consists of massive to finely laminated calcareous mudstone and siltstone with ammonoids from the lower Sinemurian (Involutum and Leslei Zones) (Taylor et al., 2001). Scholz et al. (2008) also reported bivalves including Weyla alata, Weyla $(W$.) bodenbenderi, W. titan and $W$. unca. A basal pebble-conglomerate of sequence XII is overlain by sandstone and sandy coquina beds that grade upsection into massive mudstone/ siltstone with thin beds of bioclastic limestone and interbedded ash-fall tuffs beds. The limestone contains Weyla (Lywea) unca and W. $(W$.) alata and other bivalves as well as ammonoids denoting the Sinemurian Carinatum and Jamesi Zones (Pálfy and González-León, 2000; Taylor et al., 2001).

Sequence XIII and XIV compose the uppermost $615 \mathrm{~m}$ of the Sierra de Santa Rosa Formation in the Sierra del Álamo. Sequence XIII has in its middle part turbidite beds with poorly preserved 
ammonoids that are late Sinemurian age (Pálfy and González-León, 2000), whereas sequence $\mathrm{XIV}$ is mostly terrigenous and barren of fossils.

\subsubsection{SIERRA DE SANTA ROSA FORMATION IN THE SIERRA DE SANTA ROSA}

The Lower Jurassic strata in the Sierra de Santa Rosa were first reported by Keller (1928) and Flores (1929), followed by Jaworski (1929) who provided a list of molluscan fossils that he assigned to the Lower Jurassic. Hardy (1981) described the stratigraphy and named the succession as Sierra de Santa Rosa Formation that he subdivided into lower, middle, and upper members encompassing a thickness of $1460 \mathrm{~m}$ (Figure 3A); however, this is an incomplete thickness estimate as the formation is thrust over the Proterozoic basement of the region and its upper part is covered by younger volcanic rocks.

According to the description of Hardy (1981), the lower member consists of alternating cross-bedded sandstone, calcareous mudstone, lesser volcanic pebble conglomerate and sandy limestone. The middle member is composed of bluish gray limestone, sandy fossiliferous shale, sandstone and tuffaceous mudstone beds. In its upper part it grades into fine-grained sandstone and limestone. The shale and limestone contain the best preserved fossils in the formation. The upper member consists of shale, sandstone, volcanic conglomerate and limestone. Jaworski (1929) described fossils collected from the middle member, including seven bivalve species, among them Weyla (Weyla) mexicana introduced as a new species and one ammonoid (Arietites sp.), in addition to Deroceras sp., which was previously reported by Flores (1929). Hardy (1981) considered the lower member to likely be of Triassic age.

Damborenea and González-León (1997) reported stratigraphic details of these members from three measured sections (Figure 3B) and illustrated bivalves. Section 3, which is thrust over older rocks, is located in the southwestern part of the Sierra de Santa Rosa (Figure 3) and includes part of the lower and middle members. The lower member there includes in its lower part upward-fining suc- cessions of conglomerate, coarse- to fine-grained sandstone, mudstone and siltstone, which origin was interpreted as fluvial. The middle part of this member consists of shallow marine fine-grained sandstone, calcareous shale and bioclastic to sandy limestone, where one limestone bed yielded Weyla $(W$.) alata von Buch (Damborenea and GonzálezLeón, 1997) and Weyla (W.) bodenbenderi (Scholz et al. 2008) and the ammonoid Paltechioceras from the uppermost Sinemurian (Pálfy and González-León, 2000). The upper part of this lower member is composed of interbedded coarse- to fine-grained sandstone, siltstone, calcareous mudstone and bioclastic and encrinitic limestone with occasional solitary corals.

The upper part of section 3 consists of interbedded calcareous mudstone and shaly to sandy, fossiliferous limestone beds of the lower part of the middle member. The middle member in this area, as shown by partial sections 3,4 and 5, consists of thin- to medium-bedded fossiliferous limestone (yielding bivalves and ammonoids including the early Pliensbachian Metaderoceras) and interbedded calcareous, bluish mudstone and subordinate fine-grained sandstone beds. A large number of bivalve taxa from this member were described in Damborenea and González-León (1997) and by Scholz et al. (2008), including W. (W.) alata, Weyla $(W$.$) bodenbenderi, Weyla (Lywea) unca and W. titan$ and two mound-like carbonate buildups in the section are constructed by colonial corals and bivalves (González-León et al., 2005; Hodges et al., 2015). The partly exposed upper member reported in section 5 consists of calcareous, fine- to medium-grained and locally cross bedded sandstone, calcareous mudstone with the ammonoids Metaderoceras sp., Dubariceras sp., and Fuciniceras sp. (Pálfy and González-León, 2000) and sandy bioclastic limestone.

Ammonoids from the lower, middle and upper members reported by Pálfy and González-León (2000) and subject to more ongoing studies indicate that the Sierra de Santa Rosa Formation, in the mountains of the same name, ranges in age from the late Sinemurian to the early Pliensbachian. 

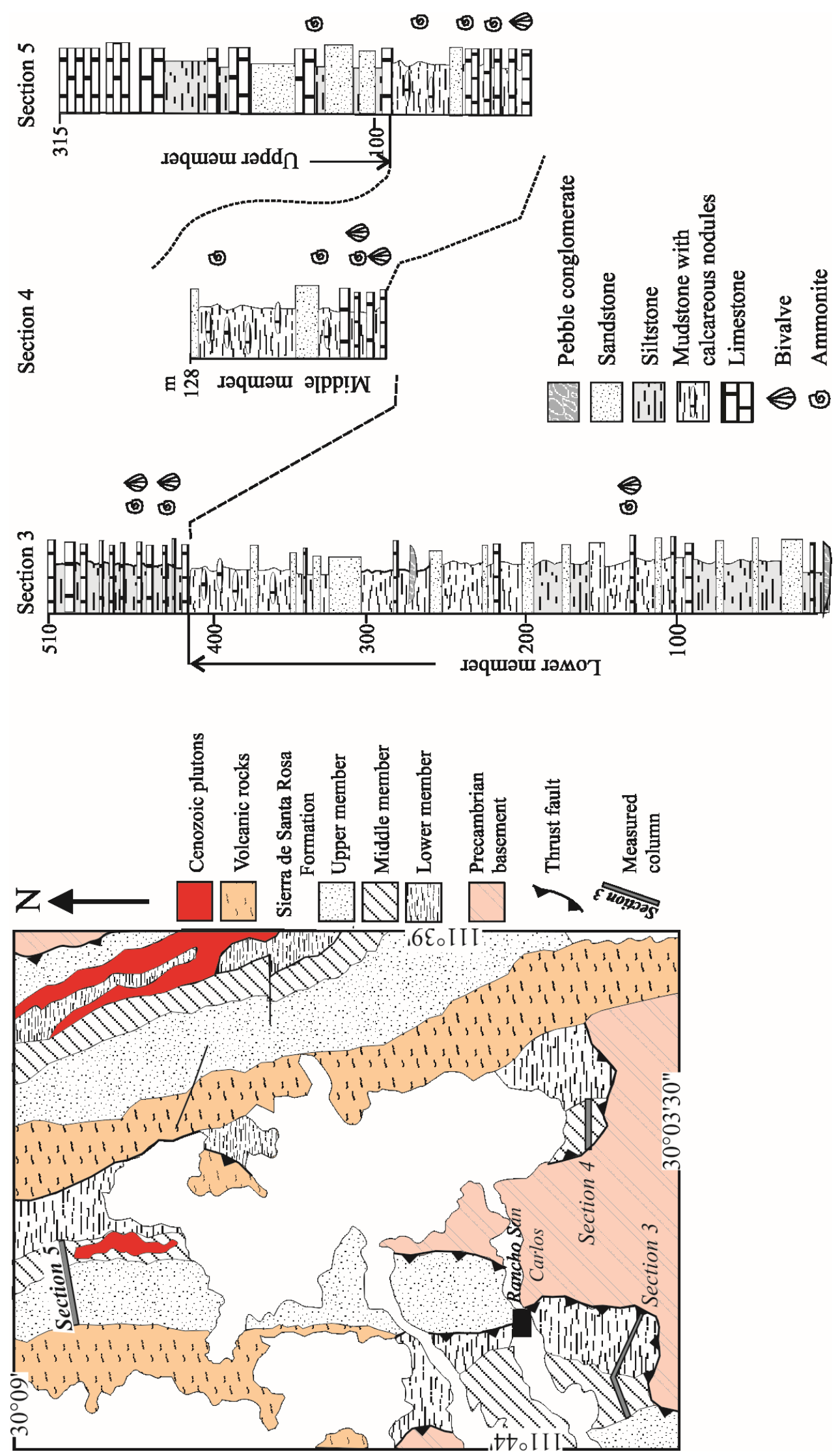
Other partly exposed successions of this formation occur in at least four other localities of northwest Sonora. For instance, in the Pozo de Serna locality, $50 \mathrm{~km}$ west of the Sierra de Santa Rosa Mountains (Figures 1 and 4), a 750 m thick section of sandstone, shale and limestone yielded ammonoids that were first assigned to the Upper Jurassic (Beauvais and Stump, 1976). These fossils were later variously reassigned to the lower Pliensbachian (Linares et al., 1997), Sinemurian to Bajocian-Bathonian (Calmus et al., 1997) and uppermost Sinemurian (Lucas et al., 1999). Based on an assemblage dominated by species of Polymorphites this section was reassigned to the lower Pliensbachian by Pálfy and González-León (2000). The youngest section of this formation crops out in the Sierra La Jojoba, located $\sim 40 \mathrm{~km}$ northwest of the Sierra de Santa Rosa (Figure 1 and 4) and according to preliminary identification of early dactylioceratid ammonoids it is now assigned to the Pliensbachian rather than the lower Toarcian (Pálfy and González-León, 2000). Weyla $(W$. ) bodenbenderi is present in the Pozos de Serna locality, $W$. titan is present in the Sierra La Jojoba and Weyla (Weyla) alata is present in both localities (Scholz et al., 2008).

\subsection{EARLY MESOZOIC ARG MAGMATISM}

A northwest-southeast trending magmatic arc, that was well developed by early Mesozoic time in southwestern North America, was constructed at a high angle to the trend of the late Paleozoic truncated margin of Laurentia (Stone and Stevens, 1988; Walker, 1988; Barth et al., 1990, 1997; Busby-Spera, 1988; Busby-Spera et al., 1990; Dickinson and Lawton, 2001; Riggs et al., 2016). The early phase of this magmatism started in Permian time and continued into the Triassic as was recorded by plutonic suites of Sonora and southeastern California. The Sonoita suite (Riggs et al., 2016) of Sierra Los Tanques (Figure 1) and surrounding areas of northwestern most Sonora apparently shows a magmatic pulse from $\sim 275$ to $221 \mathrm{Ma}$ (Arvizu et al., 2009; Riggs et al., 2012; Arvizu and Iriondo, 2015), whereas several plutonic suites in the Mojave Desert range in age from 260 to 207 $\mathrm{Ma}$ (U-Pb ages in Barth and Wooden, 2006).

A renewed, Jurassic magmatic pulse that occurred in an extensional arc is recorded by the thick accumulation of juxtaposed volcanic and volcaniclastic facies rocks and interbedded eolian craton-derived quartzarenites that are intruded by penecontemporaneous plutons (Busby-Spera et al., 1990). Among the oldest outcrops known of this arc are those of the lower Colorado River region in southwestern Arizona and southeastern California, where volcanic and plutonic rocks have yielded U-Pb ages $c a$. 190 - $158 \mathrm{Ma}$ (Tosdal and Wooden, 2015) and the Mount Wrightson Formation of southern Arizona that accumulated between 183 and $170 \mathrm{Ma}$ (in Haxel et al., 2005). Other successions in southern Arizona have U-Pb ages between $\sim 170$ and 165 Ma, e.g. the Cobre Ridge Tuff (Riggs et al., 1993) and the Topawa Group (Haxel et al., 2005). Volcanic and sedimentary succession in southeastern Arizona with ages from approximately 200 to 170 Ma (Lawton et al., 2012).

Outcrops of the Jurassic arc in northern Sonora are recognized at several localities. Volcanic and plutonic rocks of northern Sonora, mostly within the southern Papago domain, have ages from $c a$. 180 to $165 \mathrm{Ma}$ (Anderson et al., 2005), whereas an age of $c a$. $180 \mathrm{Ma}$ was reported from metarhyolites at Estación Llano (Poulsen et al., 2008) (Figure 1). From west of the town of Cucurpe (Figure 1), Mauel et al. (2011) reported a complete sedimentary and volcanic succession composed of the Basomari and Rancho San Martín formations. The Basomari Formation is a fluvial unit composed of conglomerate, sandstone and siltstone. The Rancho San Martín Formation consists of eolian quartzarenite, litharenite, dacitic ash flow tuffs, volcaniclastic conglomerate, andesitic flow breccia and lacustrine limestone. Interbedded tuffs in these units yielded $\mathrm{U}-\mathrm{Pb}$ ages of $c a$. $190 \mathrm{Ma}$ for the Basomari Formation and of $168.4 \pm 1.2 \mathrm{Ma}$ for the Rancho San Martín (U-Pb, zircon) (Leggett et al., 2007; Mauel et al., 2011; Lawton and Molina-Garza, 2014), whereas a pluton that cuts the Basomari Formation was dated at $c a .181 \mathrm{Ma}$ 


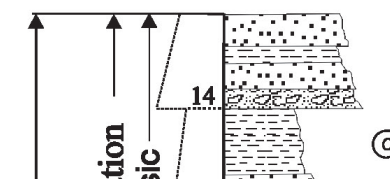
Sierra del Álamo<smiles>C1CCC1</smiles>
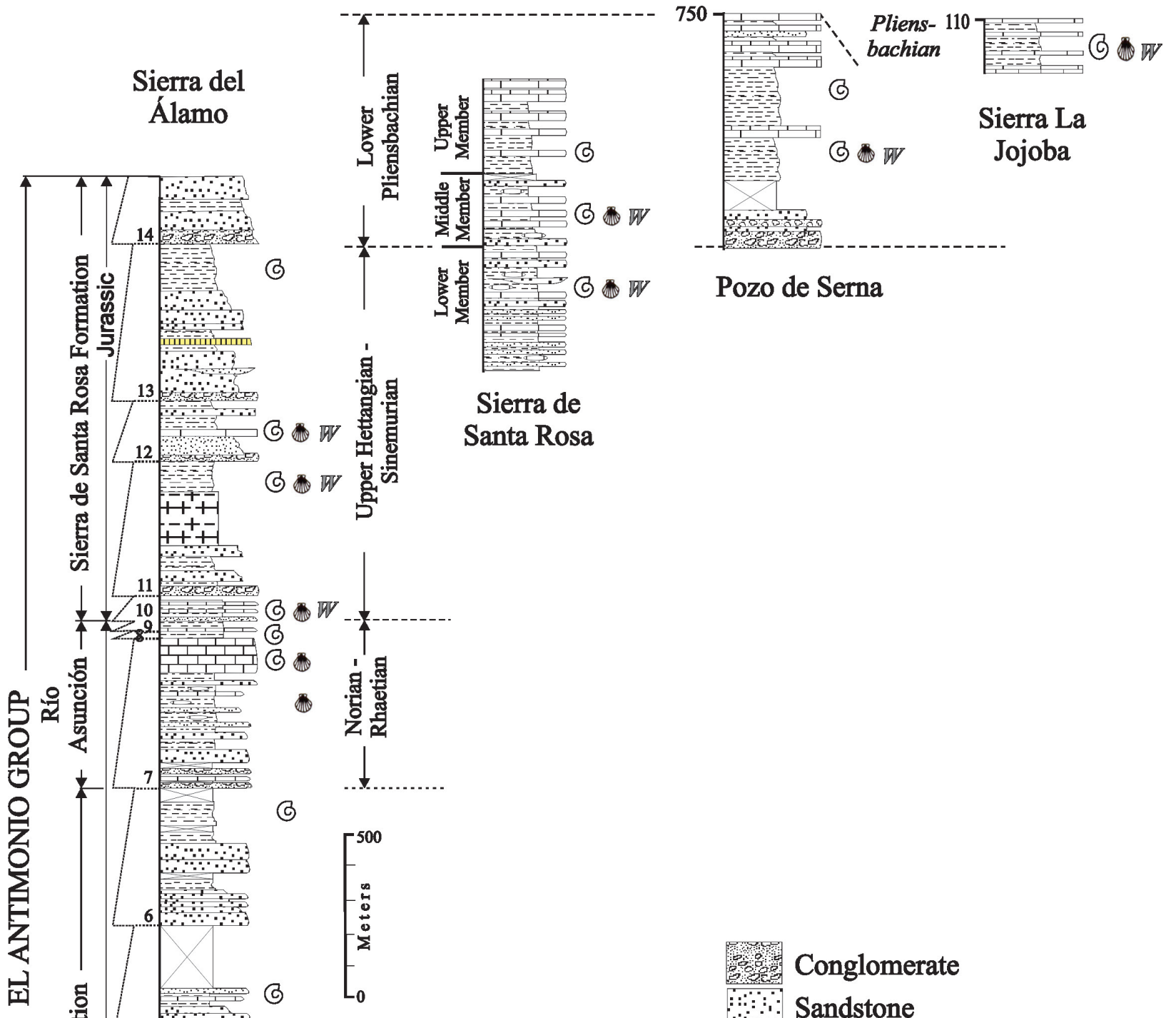
Santa Rosa

\section{Pozo de Serna}

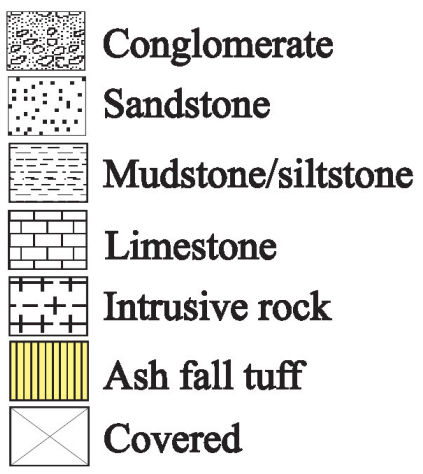

\section{(C) Ammonoid \\ (4ivivalve \\ W Weyla sp.}

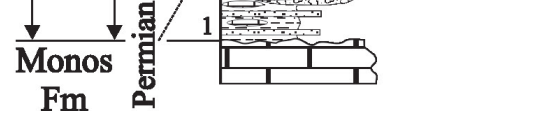

Figure 4 Correlation of the Jurassic sections of Sierra del Álamo, Sierra de Santa Rosa, Pozo de Serna and Sierra La Jojoba (locations shown in Figure 1). It shows the lower, middle and upper members of the section of the Sierra de Santa, stratigraphic position of the bivalve Weyla and ages according to the identified ammonites. 
(Lawton and Molina-Garza, 2014). The Rancho San Martín Formation is unconformably overlain by the marine, Upper Jurassic Cucurpe Formation. In northeastern Sonora, volcanic and plutonic rocks dated by Anderson et al. (2005) yielded ages $\mathrm{U}-\mathrm{Pb}$ of $c a .174 \mathrm{Ma}$, whereas detrital zircons in a quartzarenite succession yielded a younger population with peaks at $c a$. $162 \mathrm{Ma}$ (González-León et al., 2009), and unpublished data from one of us (CG-L) indicate $\mathrm{U}-\mathrm{Pb}$ zircon ages of granites at ca. 184 and $174 \mathrm{Ma}$, and a rhyolite succession of $170 \mathrm{Ma}$

The ages of rocks of the Jurassic arc in northern Sonora have been settled between $c a .190$ and 162 $\mathrm{Ma}$, and their outcrops were considered by Anderson et al. (2005) to be restricted to the north of their Mojave-Sonora domain. This domain is proposed as a zone of deformation associated with the Mojave-Sonora megashear, a left-lateral fault that transported the Caborca block from latitudes of southern California to its present position between ca. 165 - $150 \mathrm{Ma}$ (Anderson et al., 2005). At the south of this domain lies the Caborca block with rocks of the El Antimonio Group. Nevertheless, the Jurassic volcanic arc and plutonic rocks that crop out on the Caborca block in the south of the megashear, in Sierra Los Tanques and surrounding areas of northwesternmost Sonora (Figure 1) have $\mathrm{U}-\mathrm{Pb}$ ages from $c a .176$ to $160 \mathrm{Ma}$ (Quintanar-Ruiz, 2008; Izaguirre-Pompa, 2009; Arvizu and Iriondo, 2015).

\subsection{LATE JURASSIC GUGURPE FORMATION}

Near the town of Cucurpe, the Cucurpe Formation crops out in the La Cumarosa area, where it unconformably overlies the Rancho San Martín Formation, and at Rancho La Colgada where its base is not exposed (Figures 1 and 5). At the La Cumarosa, the Cucurpe Formation is unconformably overlain by the Lower Cretaceous Morita Formation and at Rancho La Colgada it is overlain by the Lower Cretaceous Rancho La Colgada Formation (Mauel et al., 2011). According to the description of Mauel et al. (2011), the Cucurpe Formation consists of a $c a .1 .5 \mathrm{~km}$ thick succession of thinly bedded shale, mudstone, tuffaceous siltstone and sandstone, subordinate granule-pebble conglomerate and scarce andesitic flows that represent upward-coarsening marine prodeltaic strata. In the section at La Cumarosa, Mauel et al. (2011) divided the formation into a fine-grained lower member that accumulated in pelagic to hemipelagic environments and an upper member that represents deposits of low-density to high-density turbidity currents and rare debris flows, slumps and slides. At some intervals, ammonoids, bivalves and belemnoids are present.

The Rancho La Colgada section was first reported by Rangin (1977), who considered it as late Oxfordian based on ammonoids. Villaseñor $e t$ al. (2005) later reported that this section is $515 \mathrm{~m}$ thick and is composed of massive to finely laminated gray to black shales with interbedded siltstone, fine-grained sandstone and subordinate mafic volcanic flows. Common ammonoids and bivalves of this section indicate an Oxfordian and early Tithonian age, but no Kimmeridgian fossils were identified. A $1 \mathrm{~m}$ thick intraformational conglomerate bed near the middle part of the section separates the Oxfordian and Tithonian strata. From the La Cumarosa section, Mauel et al. (2011) constrained the age of the Cucurpe Formation by $\mathrm{U}-\mathrm{Pb}$ geochronology from $c a .158$ to $149 \mathrm{Ma}$ and also reported Idoceras cf. I. densicostatum of early Kimmeridgian age.

\subsection{INTERPRETATION OF TEGTONIC SETTING}

Different hypotheses are proposed to interpret the tectonic setting of the Permo-Triassic and Jurassic magmatic arcs. Iriondo and Arvizu (2009) and Riggs et al. (2009) recognized the Permian magmatism in Sonora to be associated with initiation of subduction along the southwestern margin of Laurentia; younger Permian and Triassic plutons of southeastern California and western Arizona were recognized as subduction-related arc rocks (Barth et al., 1997; Barth and Wooden, 2006). According to the age of this arc $(\sim 275-221 \mathrm{Ma}$, as noted before), it must have been formed contemporaneously with movement of the California-Coahuila 


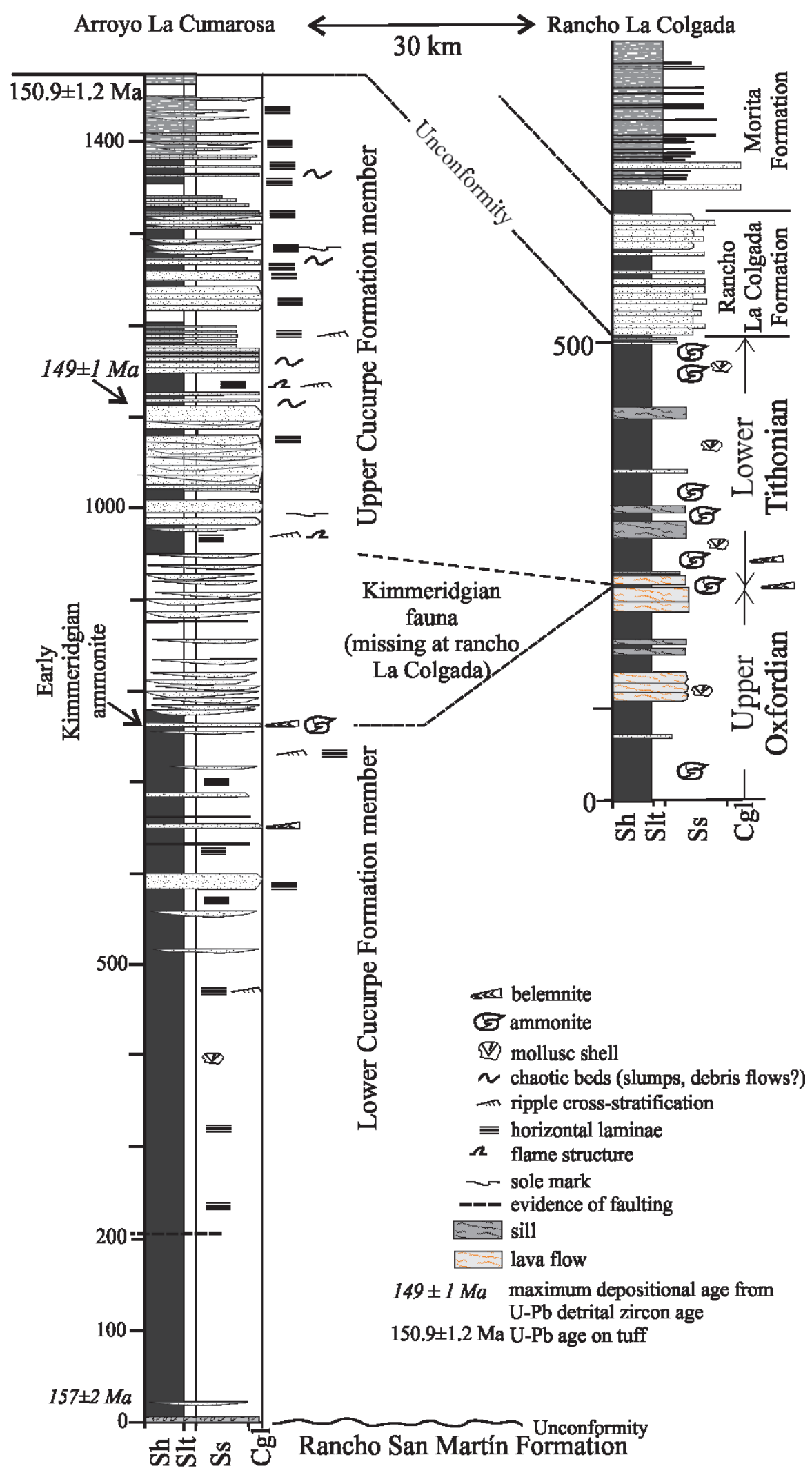

Figure 5 Stratigraphic column and correlation of the Cucurpe Formation at the La Cumarosa and Rancho La Colgada sections. These localities are near the town Cucurpe in north-central Sonora, as shown in Figure 1 (modified from Mauel et al., 2011). 
sinistral transform fault (Dickinson, 2000; Dickinson and Lawton, 2001), that was active from 281 to $248 \mathrm{Ma}$ and that truncated the southwestern margin of Laurentia. The California-Coahuila fault model proposes that the Caborca block was translated southeast, to its present position during Permian-Triassic time instead of during Jurassic time as suggested by the Mojave-Sonora megashear model.

Arvizu and Iriondo (2015) depicted the Permian-Triassic arc as extending from western North America across eastern Mexico and into northwestern South America following the final assembly of Pangea. Riggs et al. (2016) indicated that the Permian arc started to develop dominantly subaqueously and offshore in southwestern North America as there is no detrital record of it in continental rocks of that age. Riggs et al. (2016) inferred that the offshore arc that later connected with the continent at $c a .230 \mathrm{Ma}$ (late Carnian time) was probably associated with intra-arc deformation that subsequently exposed it to erosion and shed detritus to sedimentary retro-arc units, such as the Chinle Formation.

Sedimentation in the El Antimonio basin was coeval with development of the magmatic arc during latest Permian and Triassic time, as recorded by geochronology data. Ages of detrital zircons from the El Antimonio Group and the laterally equiv- alent, mostly fluvial Barranca Group (GonzálezLeón et al., 2009) of central Sonora record inception of the arc magmatism at $c a .290 \mathrm{Ma}$ and its waning in the latest Triassic, with peak ages at 255 and $228 \mathrm{Ma}$ (Figure 6A). Also, igneous clasts dated from the Antimonio and Río Asunción formations range in age from $c a .280$ to $240 \mathrm{Ma}$ (Riggs et al., 2009, 2010; Lindner, 2013). Similarly, new detrital zircon ages from 291 to $258 \mathrm{Ma}$ reported by Dobbs et al. (2016) from the mixed siliciclastic and carbonate rocks of the Monos Formation indicate that this unit likewise records Permian arc magmatism. The older ages of the zircons grains in the Monos Formation, the El Antimonio and Barranca groups suggest that arc magmatism in the region might have started by the earliest Permian, at ca. $290 \mathrm{Ma}$.

The tectonic setting of the El Antimonio basin has been proposed to be a fore-arc basin (Stanley and González-León, 1995; González-León, 1997a; Lucas et al., 1999; González-León et al., 2005). The Lower Jurassic (Hettangian-Sinemurian-Toarcian) Sierra de Santa Rosa Formation records deeper-water depositional environments and increased rates of sedimentation regarding to the Antimonio and Río Asunción formations (González-León et al., 2005). The deepening of the basin was coincident with initiation of Jurassic arc magmatism at ca. $200 \mathrm{Ma}$, as suggested by published ages of de-
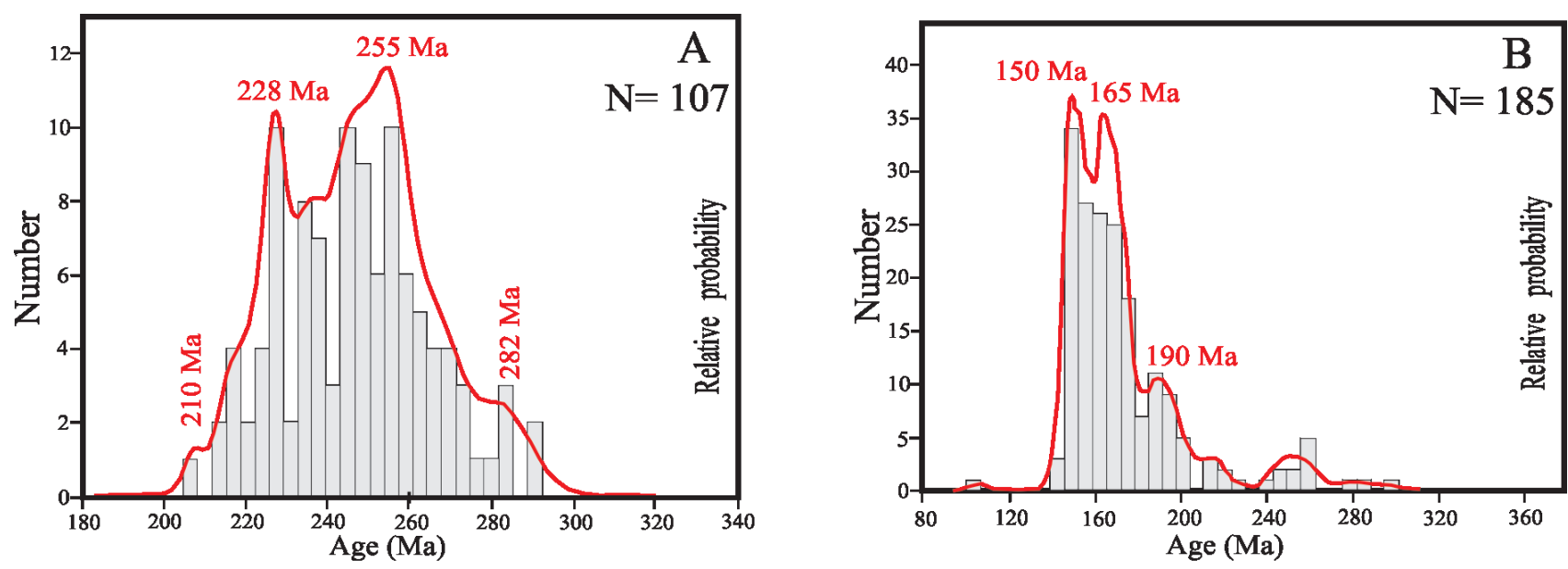

Figure 6 Histogram and relative probability curves for the less than 300 Ma detrital zircons dated from A) samples of El Antimonio and Barranca groups (data from González-León et al., 2009), and B) from samples of the Jurassic Sierra de Santa Rosa, Basomari and Lily formations (data from González-León et al., 2009) and from the Cucurpe Formation (data from Mauel et al., 2011). 
trital zircon grains from this (González-León et al., 2005) and other Jurassic formations of northern Sonora (Figure 6B) (González-León et al., 2009; Mauel et al., 2011).

Nevertheless, interpretations of the original position of this basin are speculative. Strata of the Monos Formation and El Antimonio Group altogether have been interpreted either as an allochthonous terrane that accreted to the Caborca block based mostly on its fossil content, or as strata that were relocated during the Jurassic by the Mojave-Sonora megashear, along with the Caborca block from southern California to its present-day position (Stanley and González-León, 1995; González-León, 1997a; Marzolf and Anderson, 2005).

However, a different interpretation for these rocks is that they were deposited close to the arc and near the present-day location, on the Caborca block, which had been previously displaced from southern California by the California-Coahuila transform fault (Riggs et al., 2016). A petrographic study carried out by Lindner (2013) on fluvial sandstone of the Antimonio and Río Asunción sequences (coupled with the ages of clasts and detrital zircons) suggests that their compositionally and texturally immature detritus should have been derived from and recorded the unroofing of the nearby Permo-Triassic arc that was located to the north of the basin. Similarly, Riggs et al. (2012) established a geochemical link between detrital zircon grains in the El Antimonio and Barranca groups with Triassic plutonic suites of the Mojave Desert.

Dickinson and Lawton (2001) recognized a distinction between the Permo-Triassic and Jurassic arcs, suggesting a hiatus of arc magmatism during Middle Triassic time. According to these authors, the older arc was formed to the breakup of Pangea and the younger arc developed during intracontinental extension at early phases of the breakup of Pangea. The Jurassic magmatism was of high-K, calc-alkaline composition and was emplaced episodically from $c a$. $190 \mathrm{Ma}$ to near $160 \mathrm{Ma}$ in southern Arizona and northern Sonora (Tosdal and Wooden, 2015). It is considered as a continental extensional arc that in northeastern Sonora was constructed across the Proterozoic and Paleozoic basement and in northwestern most Sonora the plutons intruded the Permo-Triassic arc rocks. In north-central Sonora, the region known as the southern Papago domain lacks exposures of an older basement (Anderson et al., 2005). The Middle Jurassic arc magmatism ended when the NWSE, fault-bounded basins in the region of Sonora and Arizona formed contemporaneously with the opening of the Gulf of Mexico. Opening of the basins may be related to opening of the Gulf of Mexico, or they may be related either to rollback of the subducting slab (Lawton and McMillan, 1999; Dickinson and Lawton, 2001) associated with the Jurassic arc, or to strike-slip faulting related to the Mojave-Sonora megashear (Anderson et al., 2005; Busby et al., 2005).

A sparse and younger magmatism that is mostly present in the Papago domain falls in the age range from 160 to $145 \mathrm{Ma}$ and consists of alkaline volcanic and plutonic rocks and interbedded sedimentary strata (Tosdal et al., 1989). Anderson et al. (2005) considered this magmatism unrelated to the calc-alkaline Jurassic arc magmatism and instead they relate it to trans-tensional mechanisms associated with the megashear. Alternatively, Mauel et al. (2011) considered it related to early extension of the Cucurpe-Altar rift, in which the Cucurpe Formation was deposited and identified as the likely source of zircon grains of $149 \mathrm{Ma}$ that are present in the younger part of this formation (Figure 6B). The Cucurpe Formation is important as it records onset of extension and marine incursion of the Gulf of Mexico waters into central Sonora (Mauel et al., 2011 ). Coeval strata in northeastern Sonora and southeastern Arizona are continental strata and interbedded volcanic rocks of the Glance Conglomerate that compose the lower part of the Upper Jurassic and Lower Cretaceous Bisbee Group. Dickinson et al. (1986) and Dickinson et al. (1989) proposed that the Bisbee Group accumulated in the Bisbee basin, which was formed by rifting associated with the incursion of an aula- 
cogen related to opening of the Gulf of Mexico. During the Late Jurassic, the northwest-trending Cucurpe-Altar and Bisbee basins were parallel depocenters separated by the basement highs of the Aldama platform in Chihuahua (Haenggi, 2002) and its probable continuation, the Cananea high in northern Sonora (McKee and Anderson, 1998). Well documented outcrops of the Cucurpe Formation in Sonora are only known from near the town of Cucurpe, in the Arroyo La Cumarosa and Rancho La Colgada sections (Figures 1 and 5). The La Cumarosa section is $c a$. $1.5 \mathrm{~km}$ thick and its U-Pb age ranges from $c a .158$ to $149 \mathrm{Ma}$ (late Oxfordian to early Tithonian), whereas the Rancho La Colgada column is an incomplete thin section with abundant ammonoids and bivalve fauna that constrain its age to the late Oxfordian and early Tithonian (Villaseñor et al., 2005). The Rancho La Colgada column, however, lacks the ammonoid faunas indicating the latest Oxfordian, the Kimmeridgian and the earliest Tithonian. An intraformational conglomerate, $1 \mathrm{~m}$ thick near the middle part of this section that has clasts of dark shale, volcanic rocks and abundant reworked ammonites, belemnites and bivalves may be a condensed section that spans the Kimmeridgian. Similarly, the single Kimmeridgian ammonite found in the Rancho La Cumarosa section was recovered from a conglomerate composed of volcanic and limestone clasts with reworked belemnites of the middle part of the section and that is closely associated with strata recording soft-sediment deformation. Mauel et al. (2011) correlated both intervals as of possible Kimmeridgian age (Figure 5).

\section{Acknowledgments}

We thank to the Arrizon Ballesteros family to permit to work during several years at Rancho San Carlos, and greatly appreciate their kind hospitality. Reviews to this manuscript by Blanca E. Buitrón, Spencer G. Lucas and Rafael Barboza Gudiño are greatly appreciated. We also thank the help of D. Szűcs in Jurassic ammonoid taxonomy and biostratigraphy. This is an ERNO-Instituto de Geología, UNAM contribution funded by internal assignation to the senior author and an MTAMTM-ELTE Paleo Contribution No. 253.

\section{References}

Alencáster de Cserna, G., 1961, Estratigrafía del Triásico Superior de la parte central del estado de Sonora: Universidad Nacional Autónoma de México, Instituto de Geología, Paleontología Mexicana, 11, Parte 1, 1-18.

Amador-Bech, J., 2010, Estrategias constructivas, simbolismo del paisaje y arte rupestre en los cerros de Trincheras del noroeste de Sonora: Anales de Antropología 44, 105-157.

Anderson, T.H., Silver, L.T., 2005. The MojaveSonora megashear -field and analytical studies leading to the conception and evolution of the hypothesis, in Anderson, T.H., Nourse, J.A., McKee, J.W., Steiner, M.B. (eds.), The Mojave-Sonora Megashear Hypothesis: Development, Assessment, and Alternatives: Geological Society of America, Special Paper, 393, 1-50.

Anderson, T.H., Rodríguez-Castañeda, J.L., Nourse, J.A., 2005, Jurassic rocks in Sonora, Mexico: relations to the Mojave-Sonora megashear and its inferred northwestward extension, in Anderson, T.H., Nourse, J.A., McKee, J.W., Steiner, M.B. (eds.), The Mojave-Sonora Megashear Hypothesis: Development, Assessment, and Alternatives: Geological Society of America, Special Paper, 393, 51-95.

Arvizu, H.E., Iriondo, A., 2015, Control temporal y geología del magmatismo Permo-Triásico en Sierra Los Tanques, NW Sonora, México: Evidencia del inicio del arco magmático cordillerano en el SW de Laurencia: Boletín de la Sociedad Geológica Mexicana, 67, 545-586.

Arvizu, H.E., Iriondo, A., Izaguirre, A., ChávezCabello, G., Kamenov, G.D., Solís-Pichardo, 
G., Foster, D.A., Lozano-Santa Cruz, R., 2009, Rocas graníticas pérmicas en la Sierra Pinta, NW de Sonora, México: Magmatismo de subducción asociado al inicio del margen continental activo del SW de Norteamérica: Revista Mexicana de Ciencias Geológicas, 26, 709-728.

Barth, A.P., Wooden, J.L., 2006, Timing of magmatism following initial convergence at a passive margin, southwestern U.S. Cordillera, and ages of lower crustal magma sources: The Journal of Geology, 114, 231-245.

Barth, A.P., Tosdal, R.M., Wooden, J.L., 1990, A petrologic comparison of Triassic plutonism in the San Gabriel and Mule Mountains, southern California: Journal of Geophysical Research, 95, 20075-20096.

Barth, A.P., Tosdal, R.M., Wooden, J.L., Howard, K.A., 1997, Triassic plutonism in Southern California: southward younging of arc initiation along a truncated continental margin: Tectonics, 6, 290-304.

Beauvais, L., Stump, T.E., 1976, Corals, molluscs, and paleogeography of Late Jurassic strata of the Cerro Pozo Serna, Sonora, Mexico: Palaeogeography, Palaeoclimatology, Palaeoecology, 19, 275-301.

Burckhardt, C., 1930, Étude synthétique sur le Mésozoïque mexicain: Mémoire de la Société Paléontologique Suisse, 49, part I, 123.

Busby-Spera, C.J., 1988, Speculative tectonic model for the early Mesozoic arc of the southwest Cordilleran United States: Geology, 16, 1121-1125.

Busby-Spera, G.J., Mattinson, J.M., Riggs, N.R., Schermer, E.R., 1990, The TriassicJurassic magmatic arc in the MojaveSonoran Deserts and the Sierran-Klamath region; Similarities and differences in paleogeographic evolution, in Harwood, D.S., Miller, M.M. (eds.), Paleozoic and early Mesozoic paleogeographic relations; Sierra Nevada, Klamath Mountains, and related terranes: Geological Society of America Special Papier 255, 325-337.
Busby, C.J., Basset, K.N., Steiner, M.B., Riggs, N.R., 2005, Climatic and tectonic controls on Jurassic intra-arc basins related to northward drift of North America, in Anderson, T.H., Nourse, J.A., McKee, J.W., Steiner, M.B. (eds.), The Mojave-Sonora Megashear Hypothesis: Development, Assessment, and Alternatives: Geological Society of America, Special Paper, 393, 359-376.

Callaway, J.M., Massare, J.A., 1989, Shastasaurus altispinus (Ichthyosauria, Shastasauridae) from the Upper Triassic of the El Antimonio district, northwestern Sonora, Mexico: Journal of Paleontology, 63, 930-939.

Calmus, T., Pérez-Segura, E., Stinnesbeck, W., 1997, New Early and Middle Jurassic fauna in the Pozos de Serna sequence (Sonora, Mexico) consequences for the identity and the position of the Caborca terrane: Comptes Rendus de l'Académie des Sciences, Earth and Planetary Sciences, 325, 257-263.

Cooper, G.A., Arellano, R.V., 1946, Stratigraphy near Caborca, northwest Sonora, Mexico: American Association of Petroleum Geologists Bulletin, 30, 606-619.

Cooper, G.A., Dunbar, C.O., Duncan, H., Miller, A.K., Knight, J.B., 1953, Permian fauna at El Antimonio, western Sonora, Mexico: Washington, U.S.A., Smithsonian Miscellaneous Collections, 119, no. 2, 111 p. Damborenea, S.E., González-León, C.M., 1997, Late Triassic and Early Jurassic bivalves from Sonora, Mexico: Revista Mexicana de Ciencias Geológicas, 14, 178-201.

Dickinson, W.R., 2000, Geodynamic interpretation of Paleozoic tectonic trends oriented oblique to the Mesozoic KlamathSierran continental margin in California, in Gehrels, G.E., Soreghan, M.J. (eds.), Paleozoic and Triassic paleogeography and tectonics of western Nevada and northern California: Geological Society of America, Special Paper, 347, 209-245.

Dickinson, W.R., Lawton, T.F., 2001, Carboniferous to Cretaceous assembly and 
fragmentation of Mexico: Geological Society of America Bulletin, 113, 1142-1160.

Dickinson, W.R., Fiorillo, A.R., Hall, D.L., Monreal, R., Potochnik, A.R., Swift, P.N., 1989, Cretaceous strata of southern Arizona, in Jenney, J.P., Reynolds, S.R. (eds.), Geologic Evolution of Arizona: Arizona Geological Society Digest, 17, 397-434.

Dickinson, W.R., Klute, M.A., Swift, P.N., 1986, The Bisbee Basin and its bearing on Late Mesozoic paleogeographic and paleotectonic reconstructions between the Cordilleran and Caribbean regions, in Abbot, P.L. (ed.), Cretaceous stratigraphy of western North America: Society of Economic Paleontologists and Mineralogists, Pacific Section, Field Trip Guidebook 46, 51-62.

Dobbs, S.C., Riggs, N.R., González-León, C., Cecil, R.M., Marsaglia, K.M., 2016, The Middle Upper Permian Monos Formation: detrital zircon and stratigraphic evidence for Laurentian subduction initiation, northwestern Sonora, Mexico: Geological Society of America, Abstracts with Programs, $48(7)$.

Dunbar, C.O., 1953, A giant Permian fusuline from Sonora: Smithsonian Miscellaneous Collections, 119(2), 14-19.

Estep, J.W., Lucas, S.G., González-León, C.M., 1997a, Middle Triassic ammonites from Sonora, Mexico: Revista Mexicana de Ciencias Geológicas, 14, 155-159.

Estep,J.W., Lucas, S.G., González-León, C., 1997b, Late Triassic (late Carnian) ammonites at El Antimonio, Sonora: Estación Regional del Noroeste, Instituto de Geología, Universidad Nacional Autónoma de México Publicaciones Ocasionales, 1, 16-18.

Flores, T., 1929, Reconocimientos geológicos en la región central del Estado de Sonora: Boletín del Instituto de Geología de la UNAM, 49, $267 \mathrm{p}$.

González-León, C.M., 1980, La Formación Antimonio (Triásico Superior-Jurásico
Inferior) en la sierra del Álamo, estado de Sonora: Revista Instituto de Geología, Universidad Nacional Autónoma de México, 4, 13-18.

González-León, C., 1997a, Sequence stratigraphy and paleogeographic setting of the Antimonio Formation (late Permian-Early Jurassic), Sonora, Mexico: Revista Mexicana de Ciencias Geológicas, 14, 136-148.

González-León, G., 1997b, The Triassic-Jurassic boundary in the Antimonio Formation from new evidences: Estación Regional del Noroeste, Instituto de Geología, Universidad Nacional Autónoma de México Publicaciones Ocasionales 1, 33-36.

González-León, C., Taylor, D.G., Stanley, G.D., Jr., 1996, The Antimonio Formation in Sonora, Mexico and the Triassic-Jurassic boundary: Canadian Journal of Earth Sciences, 33, 418-428.

González-León, C., Stanley, G.D., Jr., Taylor, D.G., 2000, Ammonoid discoveries in the Antimonio Formation, Sonora, Mexico: New constraints on the Triassic-Jurassic boundary: Journal of South American Earth Sciences, 13, 491-497.

González-León, G.M., Stanley, Jr., G.D., Gehrels, G.E., Centeno-García, E., 2005, New data on the lithostratigraphy, detrital zircon and $\mathrm{Nd}$ isotope provenance, and paleogeographic setting of the El Antimonio Group, Sonora, Mexico, in Anderson, T.H., Nourse, J.A., McKee, J.W., Steiner, M.B. (eds.), The Mojave-Sonora megashear hypothesis: Development, Assessment, and Alternatives: Geological Society of America, Special Paper, 393, 259-282.

González-León, C.M., Valencia, V.A., Lawton, T.F., Amato, J., Gehrels, G.E., Leggett, W.J., Montijo-Contreras, O., Fernández, M.A., 2009, The lower Mesozoic record of detrital zircon U-Pb geochronology of Sonora, Mexico and its paleogeographic implications: Revista Mexicana de Ciencias Geológicas, 26, 301-314. 
González-León, C.M., Lawton, T.F., Weber, R., 2011, Estratigrafía del Triásico y el Jurásico Inferior de Sonora, México, in Calmus, T. (ed.), Panorama de la geología de Sonora, México: Universidad Nacional Autónoma de México, Boletín del Instituto de Geología, $118,57-80$.

Goodwin, D.G., 1999, Paleontology, paleoecology, and depositional environments within the Upper Triassic (Norian) carbonate strata of the Antimonio Formation, northwest Sonora, Mexico: Missoula, U.S.A., University of Montana, MSc thesis, $209 \mathrm{p}$.

Goodwin, D.G., Stanley, G.D., Jr., 1997, Norian sponge and coral biostromes in the Antimonio Formation, northwestern Sonora, Mexico: Revista Mexicana de Ciencias Geológicas, 14, 160-166.

Haenggi, W.T., 2002, Tectonic history of the Chihuahua Trough, Mexico, and adjacent USA, part II; Mesozoic and Cenozoic: Boletín de la Sociedad Geológica Mexicana, 55, 38-94.

Hardy, L.R., 1981, Geology of the central Sierra de Santa Rosa, Sonora, Mexico, in Ortlieb, L., Roldán-Quintana, J. (eds.), Geology of northwestern Mexico and southern Arizona: Hermosillo, Sonora, Mexico, Geological Society of America and Universidad Nacional Autónoma de México, Instituto de Geología, Estación Regional del Noroeste, Field guide and papers, 73-98.

Haxel, G.B., Wright, J.E., Riggs, N.R., Tosdal, R.M., May, D.J., 2005, Middle Jurassic Topawa Group, Baboquivari Mountains, south-central Arizona: Volcanic and sedimentary record of deep basins within the Jurassic magmatic arc, in Anderson, T.H., Nourse, J.A., McKee, J.W., Steiner, M.B. (eds.), The Mojave-Sonora megashear hypothesis: Development, Assessment, and Alternatives: Geological Society of America, Special Paper, 393, 329-357.

Hodges, M., Stanley, G.D., González-León, C., 2015, Determining depositional age of an
Early Jurassic reef in El Antimonio Group of Sonora, Mexico, and the implications for coral recovery after the end-Triassic mass extinction: 31 st IAS Meeting of Sedimentology, Abstract Book, Kraków, Poland, $231 \mathrm{p}$.

Iriondo, A., Arvizu, H., 2009, Permian ( 275-258 $\mathrm{Ma}$ granitic magmatism in NW Sonora, Mexico: the missing link to a large continental arc event in SW North America: Geological Society of America Abstracts with Program, $41(2), 35$.

Izaguirre-Pompa, A., 2009, El basamento Paleoproterozoico ( 1.71-1.68 Ga) Yavapai en el área Mina La Herradura en el NW de Sonora: sus implicaciones para el desarrollo del margen magmático continental Mesozoico-Cenozoico del NW de México: Juriquilla, Querétaro, México, Posgrado en Ciencias de la Tierra, Universidad Nacional Autónoma de México, Unpublished M.Sc. Thesis, 201 pp.

Jaworski, E., 1929, Eine Lias-fauna aus NordwestMexiko: Abhandlungen der Schweizerischen Palaeontologischen Gesellschaft, 48(4), 12 p.

Keller,W.T., 1928, Stratigraphischebeobachtungen in Sonora (nordwest Mexico): Eclogae Geologicae Helvetiae, 21, 327-335.

Lawton, T.F., McMillan, N.J., 1999, Arc abandonment as a cause for passive continental rifting: Comparison of the Jurassic Mexican Borderland rift and the Cenozoic Rio Grande rift: Geology, 27, 779-782.

Lawton, T.F., Gilbert, J.C., Amato, J.M., 2012, Age of the Jurassic arc system in southern Arizona: Geological Society of America Abstracts with Programs, 44(3), 23.

Lawton, T.F., Molina-Garza, R.S., 2014, U-Pb geochronology of the type Nazas Formation and superjacent strata, northeastern Durango, Mexico: Implications of a Jurassic age for continental-arc magmatism in northcentral Mexico: Geological Society of America Bulletin, 126, 1181-1199. 
Lawton, T.F., Cashman, P.H., Trexler, J.H., Taylor, W.J., 2017, The late Paleozoic Southwestern Laurentian Borderland: Geology.

Leggett, W.J., Lawton, T.F., Amato, J.M., GonzálezLeón, C.M., 2007, New age constraints and geochemical data on Early to Middle Jurassic strata near Cucurpe, Sonora, Mexico: A record of the Cordilleran-Nazas arc in northcentral Sonora: Ores and Orogenesis, a Symposium Honoring the Career of William R. Dickinson: Arizona Geological Society Program with Abstracts, 148.

Linares, A, Olóriz, F., Villaseñor, A.B., 1997, Presencia de Tropidoceras flandrini (Dumortier) en Pozo de Serna, Sonora (México): Revista Española de Paleontología, 12, 257-264.

Lindner, P.J., 2013, Provenance study of latest Paleozoic and Mesozoic El Antimonio Group, Sonora, Mexico: Arizona, U.S.A., Northern Arizona University, M.Sc. thesis, $172 \mathrm{p}$.

Lucas, S.G., González-León, G.M., 1995, Ichthyosaurs from the Upper Triassic of Sonora and the biochronology of Triassic ichthyosaurs, in Jacques-Ayala, C., GonzálezLeón, G.M., Roldán-Quintana, J. (eds.), Studies on the Mesozoic of Sonora and adjacent areas: Geological Society of America, Special Paper, 301, 7-20.

Lucas, S.G., Kues, B.S., Estep, J.W., GonzálezLeón, G.M., 1997a, Permian-Triassic boundary at El Antimonio, Sonora, Mexico: Revista Mexicana de Ciencias Geológicas, 14, 149-154.

Lucas, S.G., Estep, J.W., González-León, C., Paull, R.K., Silberling, N.J., Steiner, M.B., Marzolf, J.E., 1997b, Early Triassic ammonites and conodonts from Sonora, northwestern Mexico: Neues Jahrbuch für Geologie und Paläontologie Abhandlungen, 9, 562-574.

Lucas, S.G., Estep,J.W., Molina-Garza, R.S., 1999, Early Jurassic stratigraphy and ammonites at Cerro Pozos de Serna, Sonora, Mexico, and their tectonic significance: Neues Jahrbuch für Geologie und Paläontologie Monatshefte, 1999, 357-371.

Lucas, S.G., Estep, J.W., 1999a, Triassic-Jurassic boundary in the Sierra del Álamo Muerto, Sonora, Mexico: Albertiana, 23, 36-41.

Lucas, S.G., Estep, J.W., 1999b, Permian, Triassic, and Jurassic stratigraphy, biostratigraphy, and sequence stratigraphy in the Sierra del Álamo Muerto, Sonora, Mexico, in Bartolini, G., Wilson, J.L., Lawton, T.F. (eds.), Mesozoic sedimentary and tectonic history of northcentral Mexico: Geological Society of America, Special Paper, 340, 271-286.

Lucas, S.G., Cantrell, A.K., Suazo, T.L., Estep, J.E., 2015, Carnian (Late Triassic) Ammonoids from El Antimonio, Sonora, Mexico, in Sullivan, R.M., Lucas, S.G. (eds.), Fossil Record 4: New Mexico Museum of Natural History and Science Bulletin, 67, 189-203.

Marzolf, J.E., Anderson, T.H., 2005, Lower Mesozoic facies and cross-cutting sequence boundaries; constraints on displacement of the Caborca Terrane, in Anderson, T.H., Nourse, J.A., McKee, J.W., Steiner, M.B. (eds.), The Mojave-Sonora megashear hypothesis: Development, Assessment, and Alternatives: Geological Society of America, Special Paper, 393, 283-308.

Mauel, D.J., Lawton, T.F., González-León, C.M., Iriondo, A., Amato, J.M., 201 1, Stratigraphy and age of Upper Jurassic strata in northcentral Sonora, Mexico: Southwestern Laurentian record of crustal extension and tectonic transition: Geosphere 7, 390-414.

McKee, M.B., Anderson, T.H., 1998, Massgravity deposits and structures in the Lower Cretaceous of Sonora, Mexico: Geological Society of America Bulletin, 110, 1516-1529. McRoberts, G.A., 1997, Late Triassic (NorianRhaetian) bivalves from the Antimonio Formation, northwestern Sonora, Mexico: Revista Mexicana de Ciencias Geológicas, 14, 167-177. 
Pálfy, J., González-León, C., 2000, Lower Jurassic ammonoid biostratigraphy of the Antimonio terrane, Sonora, northwestern Mexico, in Calmus, T., Pérez-Segura, E. (eds.), Cuarta reunión sobre la geología del Noroeste de México y áreas adyacentes, Libro de Resúmenes: Estación Regional del Noroeste, Instituto de Geología, Universidad Nacional Autónoma de México Publicaciones Ocasionales, 2, 87-88.

Poole, F.G., Perry, W.J., Madrid, R.J., AmayaMartínez, R., 2005, Tectonic synthesis of the Ouachita-Marathon-Sonora orogenic margin of southern Laurentia: Stratigraphic and structural implications for timing of deformational events and plate-tectonic model, in Anderson, T.H., Nourse, J.A., McKee, J.W., Steiner, M.B. (eds.), The Mojave-Sonora Megashear Hypothesis: Development, Assessment, and Alternatives: Geological Society of America, Special Paper 393, 543-596.

Poulsen, K.H., Mortensen J.K., Walford, P.G., 2008, San Francisco gold deposit, Santa Ana region, Sonora, Mexico: Laramide orogenic, intrusion-related mineralization?, in Spencer, J.E., Titley, S.R. (eds.), Ores and orogenesis: Circum-Pacific tectonics, geologic evolution, and ore deposits: Arizona Geological Society Digest, 22, 547-559.

Quintanar-Ruíz, F.J., 2008, La Herradura ore Deposit: An Orogenic Gold Deposit in Northwestern Mexico: Tucson, Arizona, U.S.A., University of Arizona, Unpublished MSc Thesis, $97 \mathrm{p}$.

Rangin, C., 1977, Sobre la presencia del Jurásico Superior con amonitas en Sonora Septentrional: Universidad Nacional Autónoma de México, Revista del Instituto de Geología, 1, 1-4.

Riggs, N.R., Mattinson, J.M., Busby, G.J., 1993, Correlation of Jurassic eolian strata between the magmatic arc and the Colorado Plateau: New U-Pb geochronologic data from southern Arizona: Geological Society of
America Bulletin, 105, 1231-1246.

Riggs, N., Barth, A.P., González-León, C.M., Walker,J.D., Wooden, J.L., 2009, Provenance of Upper Triassic strata in southwestern North America as suggested by isotopic analysis and chemistry of zircon crystals: Geological Society of America Abstracts with Program, 41(7), 540.

Riggs, N.R., Barth, A.P., Wooden, J.L., Walker, J.D., 2010, Use of zircon geochemistry to tie volcanic detritus to source plutonic rocks: An example from Permian northwestern Sonora, Mexico: Geological Society of America Abstracts with Program, 42(5), 267.

Riggs, N.R., Barth, A.P., González-León, G.M., Jacobson, C.E., Wooden, J.L., Howell, E.R., Walker, J.D., 2012, Provenance of Upper Triassic strata in southwestern North America as suggested by isotopic analysis and chemistry of zircon crystals, in Rasbury, E.T., Hemming, S.R., Riggs, N.R. (eds.), Mineralogical and Geochemical Approaches to Provenance: Geological Society of America, Special Paper, 487, 3-36.

Riggs, N.R., Oberling, Z.A., Howell, E.R., Parker, W.G., Barth, A.P., Cecil, M.R., Martz, J.W., 2016, Sources of volcanic detritus in the basal Chinle Formation, southwestern Laurentia, and implications for the Early Mesozoic magmatic arc: Geosphere, 12(2).

Scholz, A., Aberhan, M., González-León, G.M., 2008, Early Jurassic bivalves of the Antimonio Terrane (Sonora, NW Mexico): taxonomy, biogeography and paleogeographic interpretations, in Blodgett, R., Stanley, G.D. (eds.), The terrane puzzle: New perspectives on paleontology and stratigraphy from the North American Cordillera: Geological Society of America, Special Paper, 442, 269-312.

Stanley, G.D., Jr., González-León, G.M., 1995, Paleogeographic and tectonic implications of Triassic fossils and strata from the Antimonio Formation, northwestern Sonora: Geological Society of America, Special Paper, 301, 
$1-16$.

Stanley, G.D., Jr., González-León, C., 1997, New Late Triassic scleractinian corals from the Antimonio Formation, northwestern Sonora, Mexico: Revista Mexicana de Ciencias Geológicas, 4, 202-207.

Stanley, G.D., Jr., González-León, C., Sandy, M.R., Senowbari-Daryan, B., Doyle, P., Tamura, M., Erwin, D.H., 1994, Upper Triassic (Carnian-Norian) invertebrates from the Antimonio Formation, Sonora, Mexico: The Paleontological Society Memoir, 36, 33 p.

Steiner, M.B., Pinos, O., Lucas, S.G., Marzolf, J.E., Estep, J.W., 2005, Possible Early Triassic location of the Caborca Block, in Anderson, T.H., Nourse, J.A., McKee, J.W., Steiner, M.B. (eds.), The Mojave-Sonora Megashear Hypothesis: Development, Assessment, and Alternatives: Geological Society of America, Special Paper, 393, 309-328.

Stevens, C.H., Stone, P., Miller, J.S., 2005, A new reconstruction of the Paleozoic continental margin of southwestern North America: Implications for the nature and timing of continental truncation and the possible role of the Mojave-Sonora megashear, in Anderson, T.H., Nourse, J.A., McKee, J.W., Steiner, M.B. (eds.), The Mojave-Sonora Megashear Hypothesis: Development, Assessment, and Alternatives: Geological Society of America, Special Paper, 393, 597-618.

Stewart, J.H., 2005, Evidence for MojaveSonora megashear-Systematic left-lateral offset of Neoproterozoic to Lower Jurassic strata and facies, western United States and northwestern Mexico, in Anderson, T.H., Nourse, J.A., McKee, J.W., Steiner, M.B. (eds.), The Mojave-Sonora Megashear Hypothesis: Development, Assessment, and Alternatives: Geological Society of America, Special Paper, 393, 209-231.
Stone, P., Stevens, C.H., 1988, Pennsylvanian and Early Permian paleogeography of eastcentral California: Implications for the shape of the continental margin and the timing of continental truncation: Geology, 16, 330-333.

Taylor, D.G., Guex, J., Rakus, M., 2001, Hettangian and Sinemurian ammonoid zonation for the western Cordillera of North America: Bulletin de Géologie Lausanne, 350, 381-421.

Tosdal, R.M., Wooden, J.L., 2015, Construction of the Jurassic magmatic arc, southeast California and southwest Arizona, in Anderson, T.H., Didenko, A.N., Johnson, C.L., Khanchuk, A.I., MacDonald, J.H., Jr. (eds.), Late Jurassic Margin of Laurasia-A Record of Faulting Accommodating Plate Rotation: Geological Society of America, Special Paper, 513, 189-221.

Tosdal, R.M., Haxel, G.B., Wright, J.E., 1989, Jurassic geology of the Sonoran Desert region, southern Arizona, southeastern California, and northernmost Sonora: Construction of a continental-margin magmatic arc, in Jenny, J.P., Reynolds, S.J. (eds.), Geologic evolution of Arizona: Arizona Geological Society Digest, 17, 397-434.

Villaseñor, A.B., González-León, C.M., Lawton, T.F., Aberhan, M., 2005, Upper Jurassic ammonites and bivalves from the Cucurpe Formation, Sonora, Mexico: Revista Mexicana de Ciencias Geológicas, 22, 65-87.

Walker, J.D., 1988, Permian and Triassic rocks of the Mojave Desert and their implications for timing and mechanisms of continental truncation: Tectonics, 7, 685-709.

White, D., Guiza, R., 1949, Los yacimientos antimoniales de la región de El Antimonio, Estado de Sonora: México, Instituto Nacional de Investigación Recursos Minerales, 23, 48 p. 


\section{Field stops}

This field trip focuses on Jurassic and Upper Triassic stratigraphic sections including fossils in northwestern and north-central Sonora which have been the focus of national and international interest. The trip helps to acquaint you with some of the findings and problems emerging after many years of study of their stratigraphy and paleontology. During this excursion we had the opportunity to examine three different localities including the fairly continuous Triassic to Lower Jurassic section at Sierra del Álamo and a section including the lower to middle member of the Lower Jurassic rocks exposed at Sierra de Santa Rosa. During the last day we visited the Cucurpe region to see Upper Jurassic rocks and fossils which are exposed there. The Upper Triassic and Jurassic sections allow dating of the rocks and insights into their paleoecology, paleogeography also geologic and tectonic history.

Day 1. Wednesday, January $31^{\text {st. }}$ Participants arrived to Hermosillo and stayed at Hotel Gándara.

Day 2. Thursday, February $1^{\text {st. }}$ Breakfast started at 6:00 am and departure at 7:00 am to drive to the first field stop. We drove north on Hwy 15 through Santa Ana $(165 \mathrm{~km})$ then we followed west on Hwy 2 to Caborca $(100 \mathrm{~km})$ to check in at Motel El Camino. Then from Caborca we proceeded west via State Hwy 37. After $37.4 \mathrm{~km}$ we turned left (south) onto dirt road. After $4 \mathrm{~km}$ from Hwy 37 we crossed the Río Asunción dry bed, and after 5 more $\mathrm{km}$ we parked at base of hill in northeastern part of the Sierra del Álamo.

\section{STOP \# 1}

Here we spent several hours to walk into the Upper Triassic and Lower Jurassic section that crops out in the small hill located a few tens of meters just west of the stop (Figures 7 and 8). We saw first the upper part of sequence VII consisting of Norian limestone with small biostromes of sponges and corals (Figures 9A-D). We then walked into rocks of sequences VIII and IX (Figure 9E) and examined the Triassic/Jurassic contact at base of sequence $\mathrm{X}$ to see some characteristic fossils and strata of Early Jurassic age (Figure 9F). Sequences VII to IX compose the Río Asunción Formation (Norian-Rhaetian) and sequences X (upper Hettangian-lower Sinemurian) compose the lower part of the Sierra de Santa Rosa Formation.

Sequence VII in this locality is 390 m thick. Its lower part (unit 12, Figure 2) is a fluvial succession of pebble conglomerate and coarse-grained sandstone with fossil logs, which grades upward into calcareous sandstone and coquinoid limestone of shallow marine origin. The limestone beds yielded the bivalves Mysidioptera mexicana, Palaeolopha cf. haidingeriana (Emmrich), and Costatoria? sp. (identified by $S$. Damborenea in Damborenea and González-León, 1997). The upper part of this sequence (unit 13, Figure 2) is composed of the biostromal limestone with interbedded mudstone and fine-grained sandstone that laterally vary in thickness from 45 to $80 \mathrm{~m}$ (Figure 9A). Its fauna includes diverse scleractinian corals, chambered sponges and Heterastridium conglobatum (see Stanley et al., 1994), ammonoids, bivalves, brachiopods and other reefal organisms (Figures 9B-D) (Stanley et al., 1994; González-León et al., 1996; Goodwin and Stanley, 1997; Stanley and González-León, 1997; Goodwin, 1999). The small-scale reef-like biostromes produced by corals, sponges and disjectoporoids, periodically were interrupted by influx of siliciclastic sediments. The ammonoids Pinacoceras cf. metternichi, Catenohalorites and Sagenites cf. schaubachi (identified by N.J. Silberling, written communication, 1994 in González-León et al., 1996) indicate the upper Norian Columbianus and, or Cordilleranus Zone. McRoberts (1997) also reported the new bivalve species ?Lopha cordillerana and Xiaoschuiculana tozeri, as well as Propeamussium cf. P. schafhaeutli, Gervillaria sp., Myophorigonia jaworskii, Palaeocardita peruviana and Schafhaeutlia sp. Sequence VIII is composed of a 17 m thick unit of massive calcareous siltstone with scarce bivalves [Cardinioides sp. (McRoberts, 1997)], crinoids and 


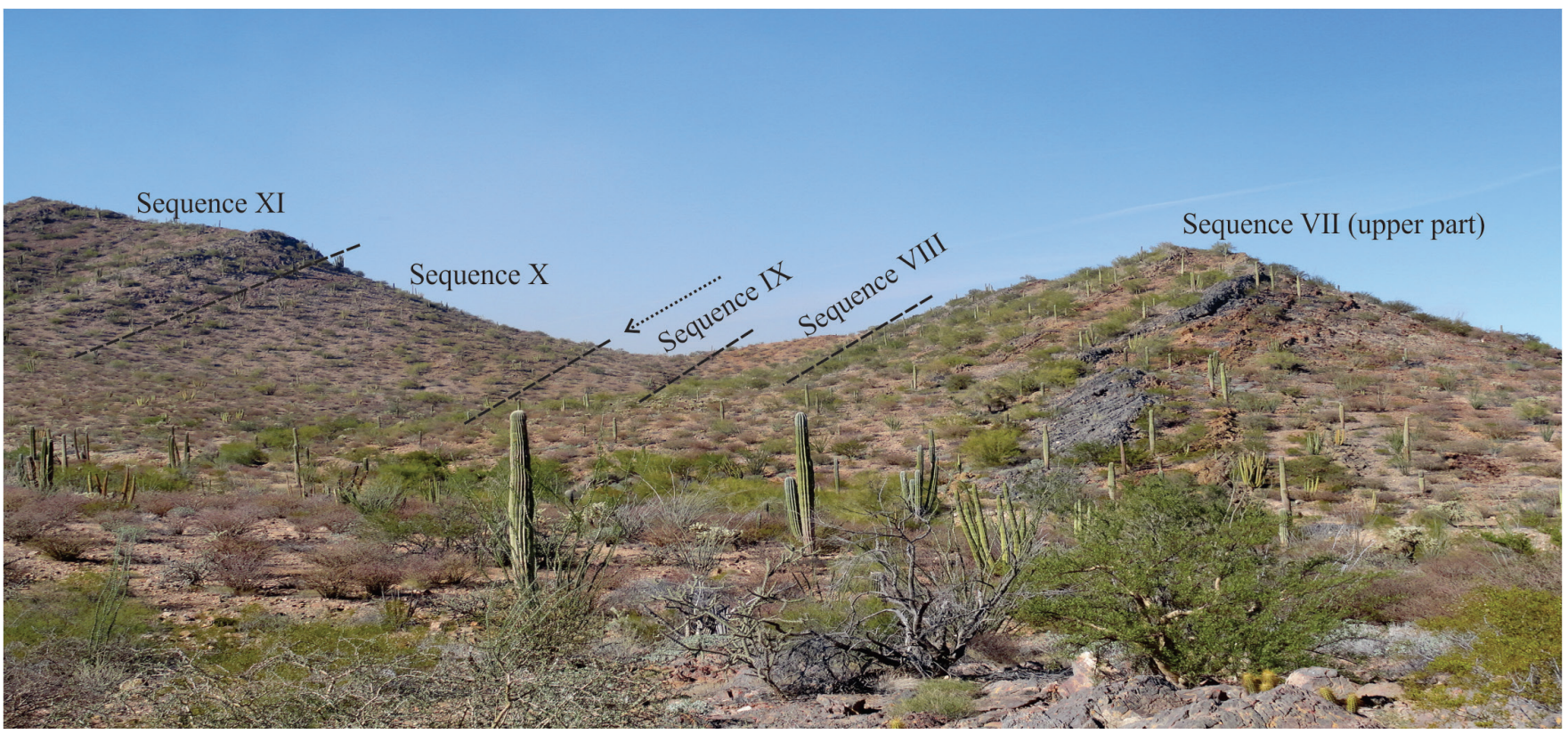

Figure 7 Outcrop of the Upper Triassic (Norian-Rhaetian) sequences VII to IX and the Lower Jurassic (uppermost Hettangian-early Sinemurian) sequences $\mathrm{X}$ and $\mathrm{XI}$. Arrow indicates the Triassic/Jurassic contact that is placed at the base of sequence $\mathrm{X}$.

the ammonoid Sagenites sp. (N.J. Silberling, written communication, 1994 in González-León et al., 1996) characteristic of the upper part of the Rhaetian Amoenum Zone. The overlying sequence IX ranges in thickness from 27 to $43 \mathrm{~m}$. Its lower part consists of a base-erosive, lenticular interval from 2 to $8 \mathrm{~m}$ thick of reddish, bioclastic to sandy limestone with mixed and reworked fossils that may indicate tempestite sedimentation (Figure 9E) (González-León et al., 2000). The fossils include ammonoids (Choristoceras, Rhacophyllites and Arcestes), nautiloids, bivalves, colonial corals, nautiloids, crinoids, gastropods, Heterastridum and bones and teeth most likely attributed to ichthyosaurs and fish. These ammonoids (González-León et al., 1996) allow assignment to the Rhaetian Crickmayi Zone. These beds grade upwards into siltstone with calcareous nodules, fine-grained sandstone and laminated to massive mudstone with the small bivalve Chalmys sp. (McRoberts, 1997) and the ammonoids Choristoceras cf. C. nobile Mojsisovics and Rhabdoceras cf. $R$. suessi of the Crickmayi Zone (González-León et al., 2000).

Sequence $\mathrm{X}$ overlies to sequence IX with an erosional surface of at least $10 \mathrm{~m}$ in a lateral distance of less than $1 \mathrm{~km}$ that forms the Triassic-Jurassic contact in this locality (González-León et al., 2000, 2005 and references therein). The lowermost part of sequence $\mathrm{X}$ consists of a 2 to $2.4 \mathrm{~m}$ thick, base-erosive, coarse-grained to pebbly sandstone (Figure 9F) that grades to its upper part to calcareous sandstone with bivalves, belemnoids, cephalopods and the ammonite Sunrisites sunrisesnsis. This bed grades upward to a $1 \mathrm{~m}$ thick yellowish-brown siltstone with scarce shell fragments, which in turn is overlain by $1 \mathrm{~m}$ thick, pebbly sandstone that in its uppermost part fines to bioturbated sandy limestone with the ammonoids Badouxia aff. columbiae, Badouxia cf. Canadensis and B. mexicana (Taylor et al., 2001). These ammonites represent the uppermost Hettangian Sunrisense and Canadensis zones that straddle the Hettangian-Sinemurian boundary (Taylor et al., 2001). The remainder of the $60 \mathrm{~m}$ thick sequence $\mathrm{X}$ consists of intercalated siltstone, mudstone and limestone, except for its uppermost $20 \mathrm{~m}$ that are covered. Siltstone and mudstone are calcareous, laminated to massive, locally bioturbated and have calcareous nodules. Limestone beds are bioclastic, up to $1 \mathrm{~m}$ thick and have common ammonites and bivalves. The ammonoids 


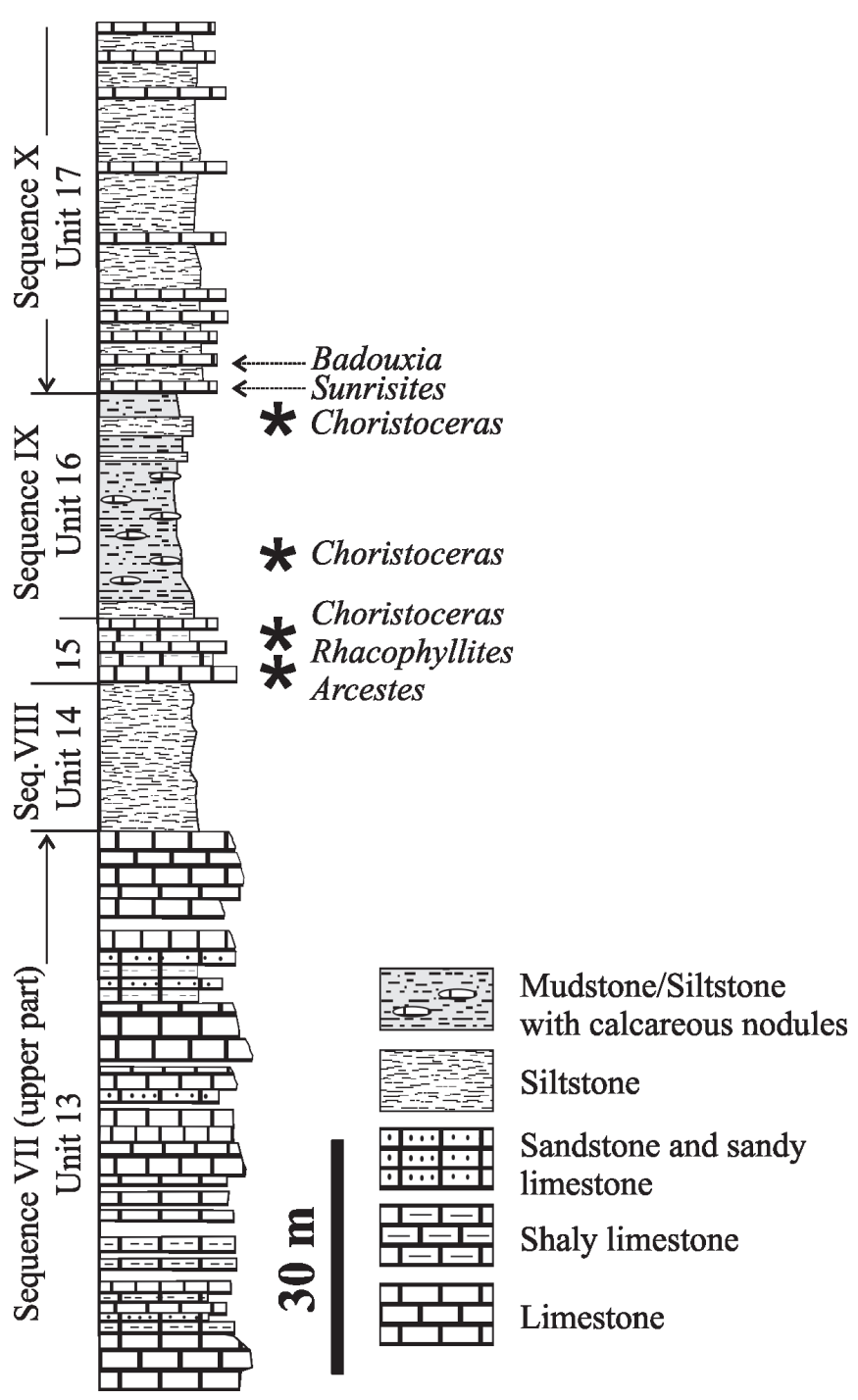

Figure 8 Stratigraphic succession of the Upper Triassic (Norian-Rhaetian) and Lower Jurassic (upper Hettangian-lower Sinemurian) strata in the El Antimonio Group, Sierra del Álamo, northwestern Sonora. Sequences VII to IX compose the Río Asunción Formation and sequence $X$ composes the lower part of the Sierra de Santa Rosa Formation. Stratigraphic position of some of the ammonites in this succession is also indicated.

Badouxia mexicana, B. canadensis, Metophioceras sp. and Coroniceras sp. from these beds provide correlation with the early Sinemurian Trigonatum Zone of the Cordilleran zonation (Taylor et al., 2001). Bivalves described by Scholz et al. (2008) from this part of the sequence include Grammatodon sulcatus, Agerchlamys zeunschae, Weyla unca, Protocardia truncata, Neocrassina gueuxi, Cardinia concinna, Cardinia? sp. A, and Lucinidae gen. et sp. indet. B.

Consequently, the Triassic-Jurassic contact in this locality is an erosional disconformity. Not only the part of the Triassic (Rhaetian) sequence is missing, also the Lower Jurassic beds above the erosional surface. These do not contain strata representing the Hettangian Spelae to Pleuroacanthitoides Zones of the Cordillera (Taylor et al., 2001).

Lunch on the outcrop. We returned to Hwy 37 and drove back to Caborca where we spent night in Motel El Camino.

Day 3. Friday, February $2^{\text {nd }}$. Breakfast at 7:00. We departed from Caborca at 8:00 am. We drove east 

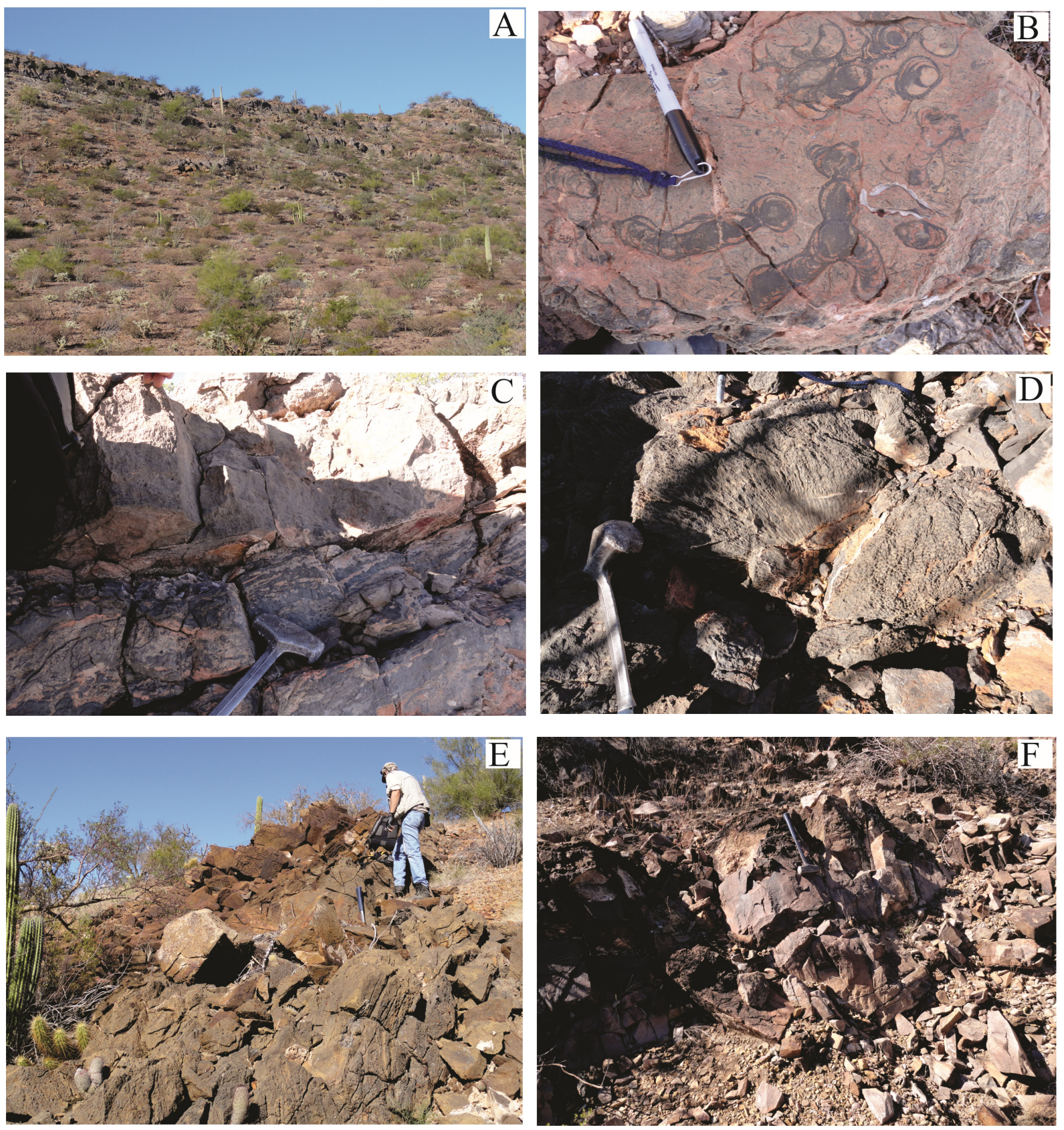

Figure 9 Outcrop photographs of: A) thick bedded Norian limestone with interbedded shale and calcareous sandstone of upper part of sequence VII. B) Sponge Fania polystoma (pen for scale is $15 \mathrm{~cm}$ long), C) Platy corals and D) branching colonial coral of the Norian upper part of sequence VII. E) Bioclastic limestone with mixed Upper Triassic fossils located at the base of sequence IX. F) Base-erosive, basal sandstone of sequence $X$. In its upper part it grades to sandy limestone with the ammonoid Sunrisites sunrisensis of upper Hettangian age. Hammer for scale is $40 \mathrm{~cm}$ long. 
on Hwy 2. At $60 \mathrm{~km}$, we turned right (south) off Hwy 2 toward the town of Trincheras. We crossed a low range of hills as we drived south, we saw a high, dark hill, El Cerro Trincheras (the Hill of the Fortifications) (Figure 10A) that is an important archaeological site. At $81 \mathrm{~km}$ we entered Trincheras, an old Municipality founded in 1775. At km 82, just outside of the town, we turned left after passing the town cemetery followed by another left turn and continued on dirt road. At 117 km we turned left toward Cerro Colorado Mine. The mountains to the left constitute the Sierra San Luis composed of a $c a$. 1.4 Ga granite and Neoproterozoic carbonate and siliciclastic rocks. At km 133, we passed through a closed gate and at 135 $\mathrm{km}$ we passed through a second gate and the road branches. We took the right fork to Rancho San Carlos located in the west-central part of the Sierra de Santa Rosa. At $136 \mathrm{~km}$ we passed through a third gate. At km 139 we reached Rancho San Carlos. At the ranch we took a sharp right turn then at $\mathrm{km} 142.6 \mathrm{~km}$ we parked at side of road.

\section{STOP \# 2}

Outcrops of the upper part of the Sierra de Santa Rosa Formation are present in this locality and are divided into lower, middle and upper members (Hardy, 1981). This section is $c a .1500 \mathrm{~m}$ thick and ranges in age from uppermost Sinemurian to lower Pliensbachian, according to ammonoids identified by Pálfy and González-León (2000). At this locality, we visited:

1. A section located $2 \mathrm{~km}$ southwest of Rancho San Carlos where the lower and middle members are exposed. The lower member is $420 \mathrm{~m}$ thick and consists mostly of shallow marine sandstone, calcareous mudstone, subordinate conglomerate and scarce limestone beds with ammonites (Paltechioceras) and bivalves (including Weyla $(W$.) bodenbenderi and $W$. (W. alata) in its lower part and subordinate limestone beds with crinoids and solitary corals in its upper part (Figure 10B). The middle member along this section consists of $90 \mathrm{~m}$ of limestone beds with complete ammonites and bivalves and interbedded mudstone and fine-grained sand- stone. Abundant and diverse bivalves from this member have been described by Damborenea and González-León (1997) and by Scholz et al. (2008), including Weyla (W.) bodenbenderi, W. (W.) alata, $W$. titan and Weyla (Lywea) unca.

We drove back to Hwy 2 and east to Madgalena for dinner and accommodations.

Day 4. Saturday, February $3^{\text {rd. }}$ Breakfast at 6:30 am and departure from Magdalena. We drove southeast toward Cucurpe. After about an hour $(\mathrm{km} 53)$ we passed the sign to Tuape. We turned right onto dirt road. We drove by winding road through hills composed of deformed Upper Jurassic strata intruded by plutons and covered by volcanic rocks of Cenozoic age. At km 66 we reached a $\mathrm{T}$ intersection and turned left $(13 \mathrm{~km}$ from main highway) on the creek to the Rancho La Colgada. At km 67 we parked in a low flat area on the creek and just crossing the cattle fence on the west we walked on the low hills with the Upper Jurassic outcrops. After noon we departed to Hermosillo for a farewell gathering and dinner.

\section{STOP \# 3}

Here we examined the section of the Upper Jurassic Cucurpe Formation for two hours. After lunch we returned to Hermosillo. At Hermosillo we checked into Hotel Gándara.

Around the Cucurpe region in north-central Sonora Lower, Middle and Upper Jurassic rocks are exposed. The Lower and Middle Jurassic sections record the late magmatic activity of a continental margin volcanic arc that extended from southwestern United States to northern and eastern Mexico, where it is known as the Nazas arc. The Upper Jurassic section is known as the Cucurpe Formation and represents mostly marine clastic sedimentation with interbedded volcanic tuffs. These Jurassic sections crop out north of the inferred trace of the Mojave-Sonora megashear, a controversial left-lateral strike-slip fault that was active during Late Jurassic time.

The nearly $1.5 \mathrm{~km}$ thick Cucurpe Formation unconformably overlies the Middle Jurassic arc as- 

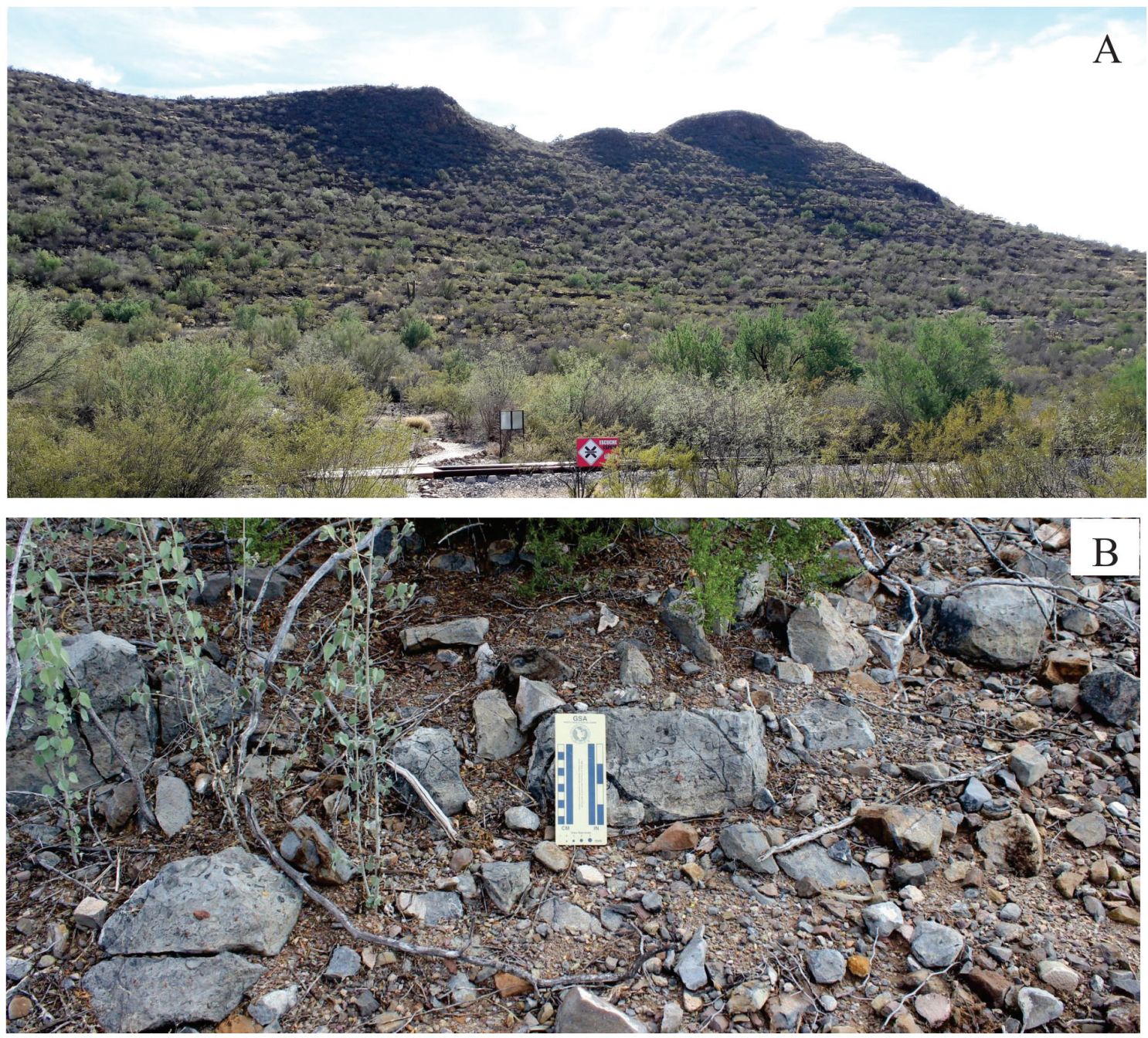

Figure 10 Cerro Trincheras, archaeological site located just south of the town of Trincheras. A site museum located at its base displays ceramics and other artifacts used by this culture (200-1450 dC; Amador-Bech, 2010). B) Outcrop of bioclastic limestone with crinoids of the lower member of the Sierra de Santa Rosa Formation in the mountains of the same name (GSA scale indicates centimeters to the left and inches to the right).

semblage and its age is constrained between $c a$. 158 and $149 \mathrm{Ma}$ by U-Pb zircon geochronology (Mauel et al., 2011). This unit was deposited in a seaway that developed through east-central Sonora in a rift basin connecting with the Gulf of Mexico. The complete type-section of this formation represents distal pelagic and turbidite marine deposits that grade upward to slope-debris flows and pro-deltaic slope marine deposits.

In this stop we visited the rancho La Colgada section, which represents the upper part of the $\mathrm{Cu}$ curpe Formation. La Colgada section is $515 \mathrm{~m}$ thick and consists in its lower part of laminated, black to light gray shale with thin interbeds of sandstone and unidentified ammonoids, belemnoids and bivalves. Upward, the section is dominated by black and gray shales that have interbeds of fine-grained sandstone, siltstone and basalt flows (Figure 11). Abundant ammonoids, belemnoids and bivalves occur in these shales. Ammonoids, including Perisphinctes (Dichotomoceras?) sp., Sequeirosia? sp., Mazapilites mexicanus (Aguilera), Schaireria neoburgensis (Oppel), Subplanitoides sp. and Glochiceras (Lingulaticeras?) indicate that this part of the Cucurpe Formation is late Oxfordian to early Tithonian age, but no Kimmeridgian fossils have 

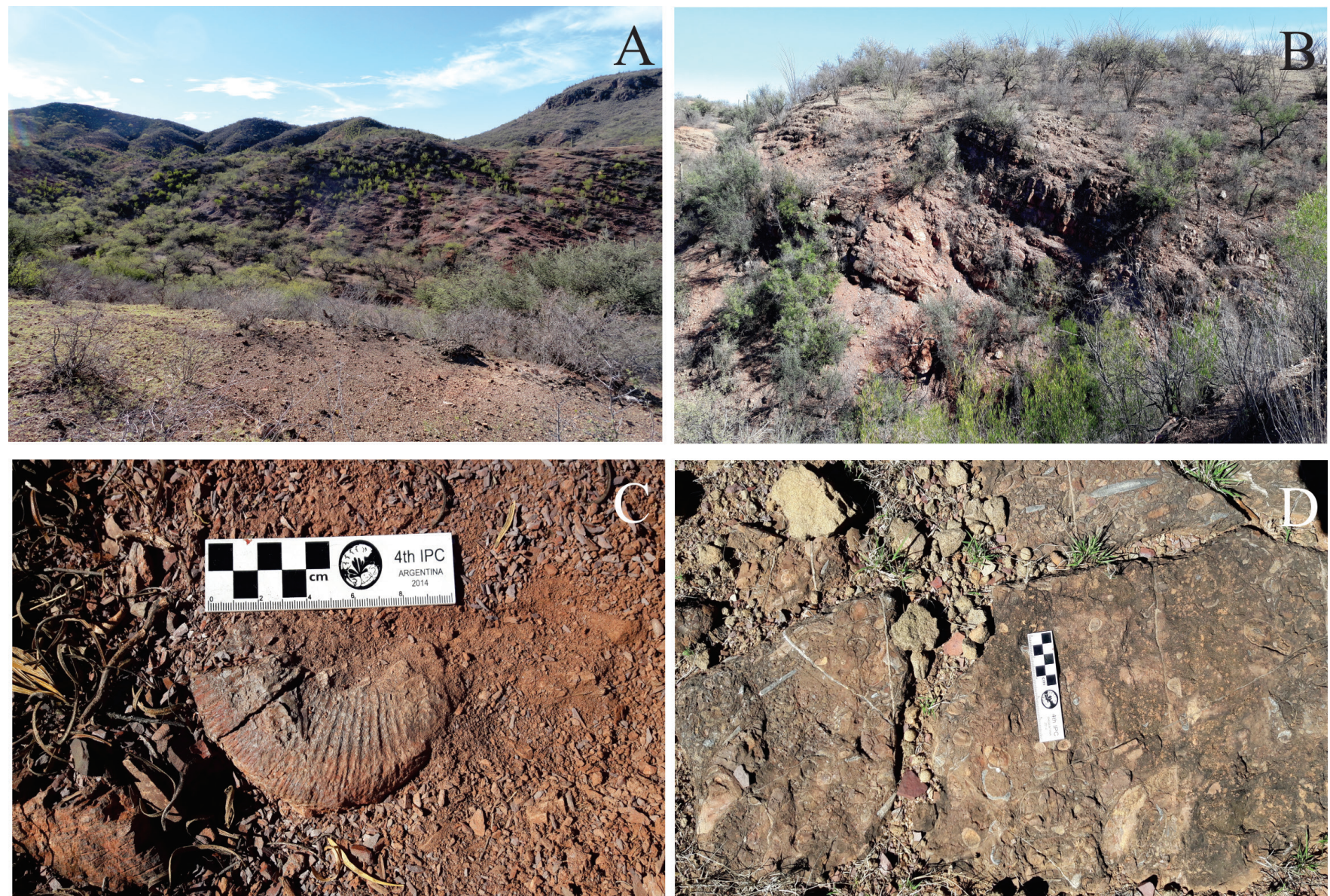

Figure 11 Outcrops photographs of the Cucurpe Formation in locality of Rancho La Colgada. A) Interbedded shale, siltstone and subordinate sandstone form the lower part of the formation. Beds show moderate dip to the southwest. B) Interbedded mafic flows and shale in its middle part. C) Floating ammonite in the lower part of the formation. D) Intraformational conglomerate, $1 \mathrm{~m}$ thick with reworked belemnite, ammonites, gastropods, bivalve, limestone and siltstone clasts in the middle part of the formation.

been identified (Villaseñor et al., 2005). Lower Cretaceous strata of the Rancho La Colgada Formation that unconformably overlie the Cucurpe Formation were dated by $\mathrm{U}-\mathrm{Pb}$ (zircons) to range from 130 to125 Ma (Mauel et al., 2011). Considering that the youngest age for the Cucurpe Formation is Tithonian, based on ammonoids and $\mathrm{U}-\mathrm{Pb}$ ages, the unconformity records both a tectonic event and a stratigraphic gap of at least 20 m.y.

Day 5. Participants departed from Hermosillo.

\section{OTHER INFORMATION FROM THE REGION}

Winter is best time for fieldwork in Sonora. January through March commonly offers cool nights and moderately hot days with temperatures vary- ing from 0 to $30^{\circ} \mathrm{C}$. This time might also be rainy if an Artic cold front brings humidity or some water vapor is entering from the Pacific Ocean. Bring a hat and some sun block for protection from the sun.

Vegetation in the countryside areas to visit is typical of the Sonoran Desert with diverse species of sahuaros, cholla and other thorny bushes for which suitable shoes for fieldwork in these kind of regions is recommended. 